PNL-5119

UC-97d

\title{
Review of Maintenance Personnel Practices at Nuclear Power Plants
}
A. D. Chockie
R. V. Badalamente
C. J. Hostick
S. C. Vickroy
J. L. Bryant
C. H. Imhoff

May 1894

Prepared for

U.S. Nuclear Regulatory Commission under Contract DE-AC06-76RLO 1830

Pacific Northwest Laboratory

Operated for the U.S. Department of Energy

by Battelle Memorial Institute 


\title{
DISCLAIMER
}

This report was prepared as an account of work sponsored by an agency of the United States Government. Neither the United States Government nor any agency thereof, nor any of their employees, makes any warranty, express or implied, or assumes any legal liability or responsibility for the accuracy, completeness, or usefulness of any information, apparatus, product, or process disclosed, or represents that its use would not infringe privately owned rights. Reference herein to any specific commercial product, process, or service by trade name, trademark, manufacturer, or otherwise, does not necessarily constitute or imply its endorsement, recommendation, or favoring by the United States Government or any agency thereof. The views and opinions of authors expressed herein do not necessarily state or reflect those of the United States Government or any agency thereof.

\author{
PACIFIC NORTHWEST LABORATORY \\ operated by \\ BATTELLE \\ for the \\ UNITED STATES DEPARTMENT OF ENERGY \\ under Contract DE-AC06-76RLO 1830
}

\begin{tabular}{|c|c|}
\hline \multicolumn{2}{|c|}{ Printed in the United States of America } \\
\hline \multicolumn{2}{|c|}{ Available from } \\
\hline \multirow{2}{*}{\multicolumn{2}{|c|}{$\begin{array}{l}\text { National Technical Information Service } \\
\text { United States Department of Commerce }\end{array}$}} \\
\hline & \\
\hline \multicolumn{2}{|c|}{5285 Port Royal Road } \\
\hline \multicolumn{2}{|c|}{ Springfield, Virginia 22161} \\
\hline \multirow{2}{*}{\multicolumn{2}{|c|}{$\begin{array}{l}\text { NTIS Price Codes } \\
\text { Microfiche A01 }\end{array}$}} \\
\hline & \\
\hline \multicolumn{2}{|c|}{ Printed Copy } \\
\hline & \\
\hline Pages & Codes \\
\hline $001-025$ & A02 \\
\hline 026-050 & A03 \\
\hline 051-075 & $\mathrm{A} 04$ \\
\hline 076-100 & A05 \\
\hline $101-125$ & $A 06$ \\
\hline $126-150$ & $\mathrm{~A} 07$ \\
\hline 151-175 & $A 08$ \\
\hline $176-200$ & A09 \\
\hline $201-225$ & A010 \\
\hline $226-250$ & A011 \\
\hline $251-275$ & A.012 \\
\hline $276-300$ & A013 \\
\hline
\end{tabular}


A.D. Chockie

R.V. Badalamente

C.J. Hostick

S.C. Vickroy

J.L. Bryant

C.H. Imhoff

May 1984

Prepared for

Division of Human Factors Safety Office of Nuclear Reactor Regulation U.S. Nuclear Regulatory Comission NRC Fin B2360

Pacific Northwest Laboratory Richland, Washington 99352 


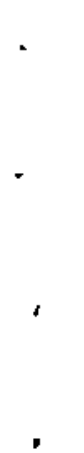
.

, 
SUMMARY AND CONCLUSIONS

As part of the Nuclear Regulatory Commission (NRC) sponsored Maintenance Qualifications and Staffing Project, the Pacific Northwest Laboratory (PNL) has conducted a preliminary assessment of nuclear power plant (NPP) maintenance practices. As requested by the NRC, the following areas within the maintenance function were examined: personnel qualifications, maintenance training, overtime, shiftwork and staffing levels. The purpose of the assessment was to identify the primary safety-related problems that required further analysis before specific recommendations can be made on the regutations affecting NPP maintenance operations.

The safe and efficient maintenance of a NPP is a function of several interrelated factors. The quality or type of training is only one such factor. Other critical factors include the skills, education and experience of the individuals, the number of maintenance personnel available, and the stress and fatigue of the specific jobs/tasks. Refore recommendations for the promulgation of regulations on specific aspects of NPP maintenance can be made, it is imperative that the impact of the regulations on the other aspects of maintenance be examined and understood. Without this understanding, the changes imposed on one aspect of the maintenance operation may have unexpected and detrinental safety impacts in another area. Therefore, this preliminary assessment of NPP maintenance practices was conducted, with the following three basic conclusions:

1. The NRC needs to clarify the current regulatory guidance so that the use of the regulations is more consistent.

2. There is a significant lack of verification of maintenance personnel qualifications to ensure that the individual assigned to the maintenance task/job has the necessary skills, knowledge and ability.

3. The maintenance training programs are inadequately documented. This problem results from the following

- Job task analysis is not being performed to document those specific areas where training is required. 
- Criteria for evaluating the students, instructors and/or overall program performance are not standardized throughout the industry.

- Interpretation of the current regulatory requirements is inconsistent; therefore, the importance that NPPs place on training varies.

Of these three, the key issue underlying the proposed regulations and concerns expressed by maintenance managers during our discussions was the current lack of proper verification of personnel qualifications. The quality and content of the training and experience varies widely for "qualified" individuals performing the same job functions at different plants. The difficulty is in attempting to identify this difference. The lack of or inconsistency in training and experience records and the inability to access and evaluate these records have lead many utilities to ignore such records in evaluating staff qualifications. There is a significant need for accrediting training programs, particularly journeyman or journeyman-type training.

The following are summaries of the major safety-related problems that need to be examined for each issue before recommendations can be made on regulations addressing maintenance staffing practices.

PERSONNFL QUAL IFICATIONS

Two main safety-related problem areas need to be analyzed before recomnendations can be developed on potential improvements to the qualifications requirements and selection methods:

1. Verifying and assuring that plants are staffed with qualified maintenance personnel is difficult for the following reasons:

- Standard job classifications are lacking.

- The quality and content of the training and educational background that maintenance personnel receive varies widely.

- The methods of documenting the skills, knowledge, and abilities of maintenance of personnel vary, and acquiring such documentation is difficult. 
2. Specific regulatory guidance on necessary basic skills, knowledge and abilities are lacking, leading to inconsistent interpretation of existing qualification requirements. This has resulter in the following:

- The selection and screening criteria of new employees vary.

- No standard, consistent basis exists for developing maintenance training programs.

TRAINING

Section 306 of the 1983 Waste Management Bill directs the NRC to establish instructional requirements for civilian NPP licensee personnel training programs and to report to Congress, detailing their compliance actions. The NRC action plan developed as a result of the TMI-2 accident directs an increase in the education, experience, and training requirements for operators, senior operators, supervisors, and other personnel to substantially improve their capability to perform their duties.

Substantial improvements are required in understanding and operating NPP maintenance training programs before the objectives of Section 306 and TAP Task I.A.? can be realized. Several major safety-related areas need to be analyzed or resolved before recommendations can be made on specific improvements to the NRC training regutations:

- Current regulatory guidance on training is incomplete.

- Job task analysis efforts are not used in developing training programs.

- The knowledge, skills, abilities of NPP maintenance training staff vary.

- Documentation of maintenance training programs and evaluation criteria of students, instructors and the program are inconsistent. 
SHIFTWORK

The following safety-related problem areas were identified for maintenance shiftwork:

- The description of shiftwork coverage in the Final Safety Analyses Reports (FSARs) for maintenance personnet is generally incomplete.

- Often nonqualified personnel make repairs when maintenance personnel are not on duty.

- Workload fluctuations with single maintenance shiftwork result in increasing amounts of overtime for maintenance personnel.

OVERTIME

The following items are the major safety-related issues concerning maintenance overtime work:

- A "reasonable amount" of overtime was indicated to be 10 to $12 \%$. However, developing a technical basis for determining a reasonable amount of overtime required for maintenance personnel in NPPS is needed. Factors that influence the amount of overtime work include staff size, training of personnel, the age of the plant equipment, union policies, corporate policies, worker expectations, and preventive maintenance programs.

- Initial staffing requirements for new facilities are usually underestimated because of the utility corporate philosophy that additional personnel should be justifiable and verifiable through concrete operating data. This often results in maintenance being short-handed and behind in its tasks. 
STAFF ING

The following are the major safety-related problems identified in maintenance staffing:

- Determining maintenance staffing level requirements is difficult because it depends upon many factors, such as personnel qualifications, training, maintenance tasks required, overtime and shiftwork policies, and size, type, and age of plant. Therefore, consistent methodology exists for estimating maintenance staff size requirements in the NPP industry.

- The NRC neither requires nor offers significant guidance for developing documented plans that incorporate key staffing factors in determining staffing levels.

- The NRC has no mechanism to determine the adequacy of the maintenance staffing plans, as presented in the FSARs. 


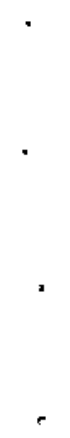


CONTENTS

SUMMARY AND CONCLUSIONS $\ldots \ldots \ldots \ldots \ldots \ldots \ldots \ldots \ldots \ldots \ldots \ldots \ldots \ldots \ldots \ldots \ldots \ldots \ldots \ldots \ldots$

PERSONNEL QUALIFICATIONS $\ldots \ldots \ldots \ldots \ldots \ldots \ldots \ldots \ldots \ldots \ldots \ldots \ldots \ldots \ldots \ldots$

TRAINING $\ldots \ldots \ldots \ldots \ldots \ldots \ldots \ldots \ldots \ldots \ldots \ldots \ldots \ldots \ldots \ldots \ldots \ldots \ldots \ldots$

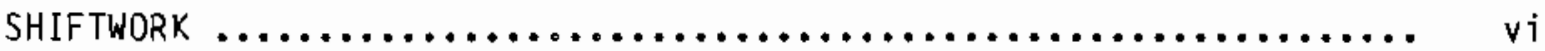

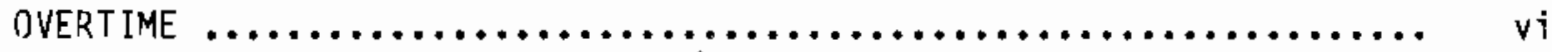

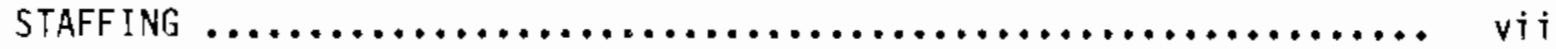

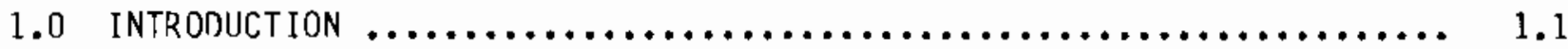

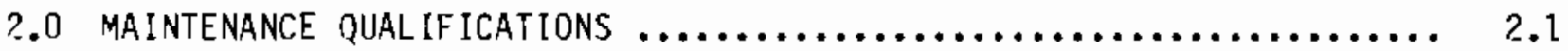

2.1 QUALIFICATION REQUIREMENTS/REGIJLATORY GUIDANCE $\ldots \ldots \ldots \ldots \ldots \ldots \ldots .1$

2.1 .1 ANSI/ANS 3.1 Requi rements $\ldots \ldots \ldots \ldots \ldots \ldots \ldots \ldots \ldots \ldots . \ldots \ldots$

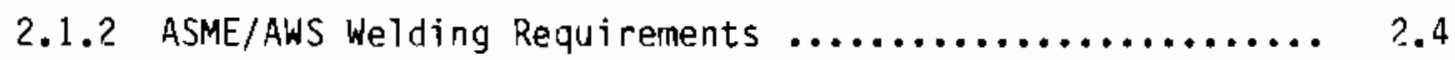

2.2 CURRENT UTILITY PRACTICES/CONCERNS $\ldots \ldots \ldots \ldots \ldots \ldots \ldots \ldots \ldots \ldots \ldots$

2.2.1 Maintenance Staff Turnover ................... 2.5

2.2.2 Selection Qualifications $\ldots \ldots \ldots \ldots \ldots \ldots \ldots \ldots \ldots \ldots .6 \ldots \ldots \ldots$

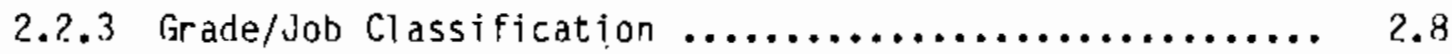

2.2.4 Maintenance Personnel Qualifications Assurance ....... 2.10

2.3 SUMMARY OF MAIN PERSDNNEL QUALIFICATIONS ISSUES $\ldots \ldots \ldots \ldots \ldots \ldots . . \ldots$

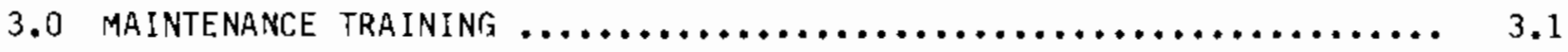

3.1 TRAINING AND EDUCATION $\ldots \ldots \ldots \ldots \ldots \ldots \ldots \ldots \ldots \ldots \ldots \ldots \ldots \ldots \ldots \ldots \ldots$

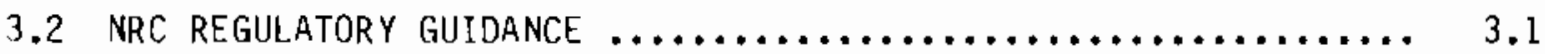

3.3 PROBLEMS IN NPP MAINTENANCE TRAINING $\ldots \ldots \ldots \ldots \ldots \ldots \ldots \ldots \ldots \ldots$

3.3.1 Utility Management of Training $\ldots \ldots \ldots \ldots \ldots \ldots \ldots \ldots . . \ldots .6$

3.3.2 Plant Training Programs ..................... 3.9

3.4 Summary OF MaInTEnance TRAining $\ldots \ldots \ldots \ldots \ldots \ldots \ldots \ldots \ldots \ldots \ldots \ldots .11$ 
4.0 Maintenance Shiftwork $\ldots \ldots \ldots \ldots \ldots \ldots \ldots \ldots \ldots \ldots \ldots \ldots \ldots \ldots \ldots \ldots, 4.1$

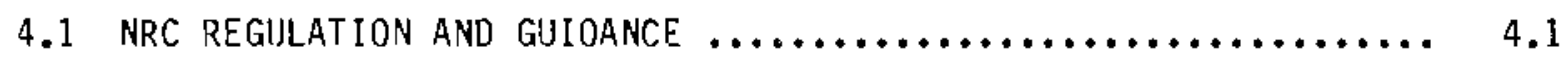

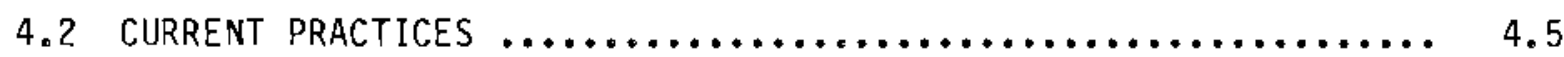

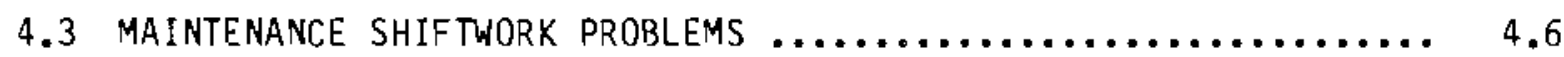

4.3.1 Maintenance Coverage $\ldots \ldots \ldots \ldots \ldots \ldots \ldots \ldots \ldots \ldots \ldots, 4.5$

4.3.2 Effect of Shiftwork on Personnel
and Their Performance ........................... 4.7

4.4 SUMMARY OF MAINTENANCE SHIF TWORK ISSUES $\ldots \ldots \ldots \ldots \ldots \ldots \ldots \ldots . .9 \ldots \ldots$

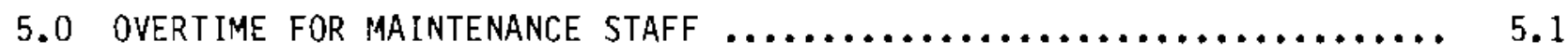

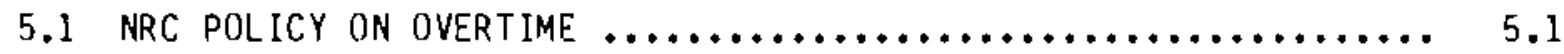

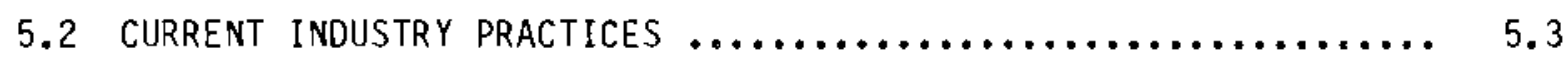

5.3 MAJOR PROBLEM AREAS WITH OVERTIME $\ldots \ldots \ldots \ldots \ldots \ldots \ldots \ldots \ldots \ldots, 5.4$

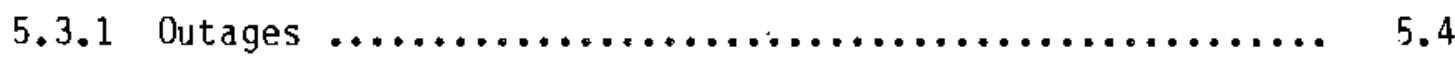

5.3.2 Preventive Maintenance Programs $\ldots \ldots \ldots \ldots \ldots \ldots \ldots \ldots .6 .6$

5.4 HIGHLIGHTS OF OVERTIME PROBLEM AREA $\ldots \ldots \ldots \ldots \ldots \ldots \ldots \ldots \ldots . .7$

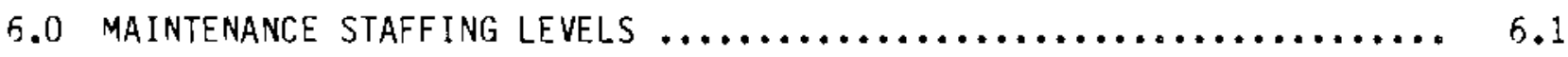

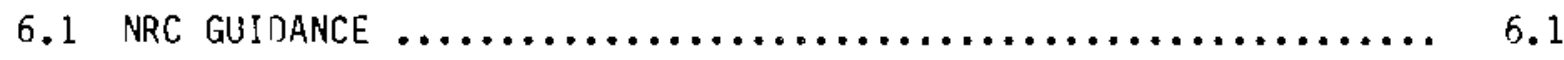

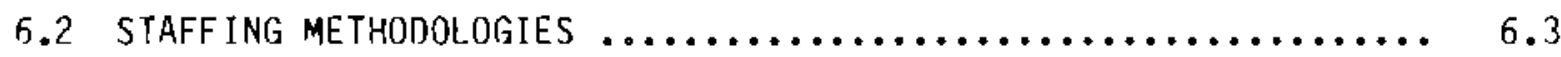

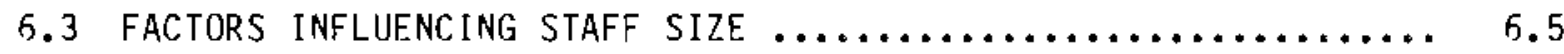

6.3.1 Physical Factors Affecting Staffing Levels $\ldots \ldots \ldots \ldots .6 .6$

6.3.2 Management Decisions Affecting Staffing Levels ....... 6.8

6.4 STAFFing SECTION SUMMARY/RECOMMENDATIONS $\ldots \ldots \ldots \ldots \ldots \ldots \ldots \ldots .6 .10$

6.4.1 Staffing Requirements Framework .................. 6.10

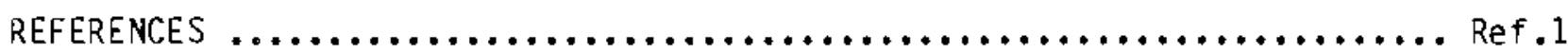




\section{FIGURES}

3.1 Maintenance Personnel Standards and Regulations $\ldots \ldots \ldots \ldots \ldots \ldots \ldots .3 .5$

6.1 FSAR Excerpt on Staffing Levels $\ldots \ldots \ldots \ldots \ldots \ldots \ldots \ldots \ldots \ldots \ldots \ldots . . . \ldots \ldots$

6.2 Comparison of Maintenance Staffing Levels for 1, 2, and

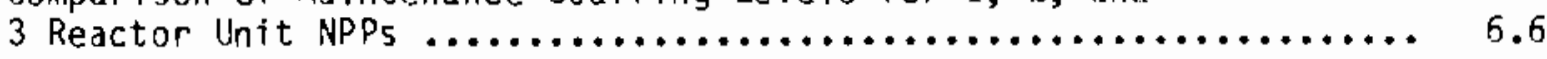

6.3 Comparison of Maintenance Staffing Levels for Plants Using Westinghouse PWRs and General Electric BWRs

TABLES

2.1 Minimum Education and Experience Requirements for NPP

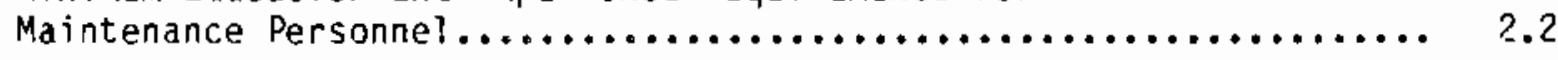

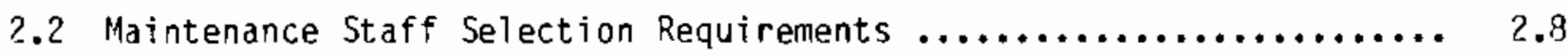

2.3 FSAR Qualification Requirements - Referenced

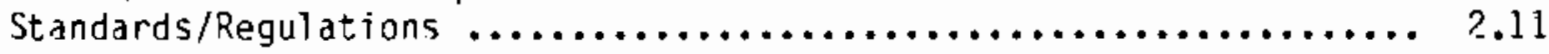

4.1 Minimum Staffing Requirements for NRC Licensees for Nuclear

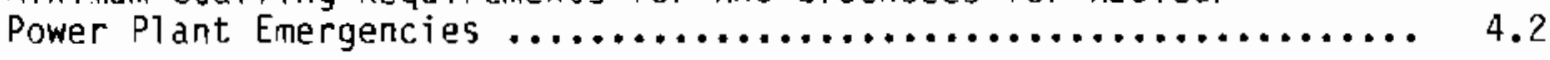

4.2 Minimum Shift Crew Composition - Single Unit Facility ............ 4.4

4.3 Summary of Interview Opinions of the Advantages/Disadvantages of Single vs. Multiple Shifts

5.1 Summary of Federal Guidelines and Regulations on Working Hours in Four Industries $\ldots \ldots \ldots \ldots \ldots \ldots \ldots \ldots \ldots \ldots \ldots \ldots \ldots \ldots \ldots, 5.2$

5.2 Annual Maintenance Overtime for Related Industries $\ldots \ldots \ldots \ldots \ldots \ldots .5 .3$

6.1 Maintenance Staffing Levels $\ldots \ldots \ldots \ldots \ldots \ldots \ldots \ldots \ldots \ldots \ldots \ldots \ldots \ldots \ldots \ldots \ldots \ldots \ldots, 2$ 


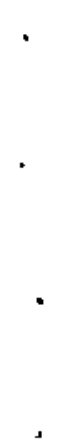




\subsection{INTRODUCTION}

The Pacific Northwest Laboratory (PNL), operated by Battelle Memorial Institute, conducted a study for the Nuclear Regulatory Commission (NRC) as part of the NRC Safety Technology Program. The objective of this study, the Maintenance Qualifications and Staffing Project, was to develop the technical basis and recommendations for policies covering maintenance staffing practices in nuclear power plants (NPPs) for improved plant safety. To develop this technical basis and policy recommendations, the key maintenance areas needing further, detailed analysis have been identified.

The first objective of this report was to document the problem areas associated with the issues of qualifications, training, shiftwork, overtime, and staffing of NPP maintenance personnel. The second objective was to identify safety-related problem areas. From these problem areas, we identified safetyrelated problems that need to be examined in more detail before specific recommendations can be made.

Two major documents direct industry and the NRC to improve the qualifications of NPP maintenance personnel. The first, Section 306 of the 1983 Waste "lanagement Bill, directs the NRC to promulgate guidance for the training and qualifications of NPP operators, supervisors, technicians and ather appropriate personnel. As it relates to inaintenance personnel, Section 306 requires the establishment of instructional requirements. The second document, the Three Mile Action PIan (TAP), Task I.A.2., requires that the education, experience and training requirements for operators, senior operators, supervisors and other personnel be increased. The TAP proposes that licensees justify the acceptability of their training programs. The TAP also proposes that the NRC audit the plants to assure that training is formalized and structured.

The information presented in this report on the current regulatory guide1 ines, industry practices and major safety-related factors was acquired from a wide variety of sources. Bocuments that were examined included regulatory guides and their backup reports, conference papers, reports and journal articles on the current state of NPP maintenance, internal utility/plant 
maintenance assessment studies, and safety analysis reports. Project members al so contacted many organizations and individuals in the NPP maintenance field. Discussions were held with maintenance management personnel at utility organizations representing 45 NPPs - 28 operating plants and 17 under construction.

NPP maintenance programs are complex operations consisting of many interrelated activities. The structure of these activities, their relationships to other maintenance efforts, and their relative importance in the overall plant maintenance program varies from one utility to another and from one plant to another. The following chapters present a preliminary examination of these variations, the interrelationships and the implications on plant safety for current maintenance qualification requirements, training programs, shiftwork and overtime practices, and staffing methods and levels.

This report is divided into 6 chapters. Chapters 2.0 through 6.0 examine the qualifications, training, shiftwork, overtime and staffing levels issues, respectively. For each issue, the regulatory guidance is reviawed, the current industry practices and problems are documented, and the major safety-related problems that warrant further study are identified. 


\subsection{MAINTENANCE QUALIF ICATIONS}

The safe and efficient operation of a nuclear power plant (NPP) highly depends on the quality of the plant personne1. In recent years, much attention has been focused on the qualifications of the operations staff to safely operate the plant. Although receiving less attention, the qualifications of the maintenance staff have some implications for NPP safety also.

In this chapter, current regulatory requirements and industry practices for maintenance staff qualifications are described. Also, major concerns associated with maintenance staff qualifications are identified and major safetyrelated problem areas that warrant further study are addressed.

\subsection{QUALIFICATION REQUIREMENTS/REGULATORY GUIDANCE}

Qualification requirements are defined as the set of criteria by which an individual is found acceptable for performing maintenance tasks. The NRC's regulatory guidance in this area is specified in Regulatory Guide 1.8, "Personnel Qualification and Training." Each applicant for a license to operate a NPP is required by paragraph $50.34(\mathrm{~b})(\mathrm{g})(\mathrm{i})$ of 10 CFR 50 to include information on the qualifications of plant personnel. Regulatory Guide 1.8 describes the method that is acceptable to the NRC staff for complying with these requirements. ANSI/ANS (American National Standards Institute and American Nuclear Society) Standard 3.1, which Regulatory Guide 1.8 endorses, details the education, experience, and training criteria that NPPs are to satisfy.

The most recent issue of Regulatory fuide 1.8, dated September 1980, endorses the December 1979 Draft ANSI/ANS Standard 3.1. This standard has since been superceded by a December 1981 version entitled "Selection, Tualifications and Training of Personnel for Nuclear Power Plants" (ANSI/ANS 3.1-1981) and is discussed below.

\subsubsection{ANS1/ANS 3.1 Requirements}

The minimum education and experience specified in ANSI/ANS 3.1-1981 are shown in Table 2.1. Briefly, the table states the following educational and experience requirements: 
TABLE 2.1. Minimum Education and Experience Requirements for NPP Maintenance Personnel (ANSI/ANS 3.1 - 1981)

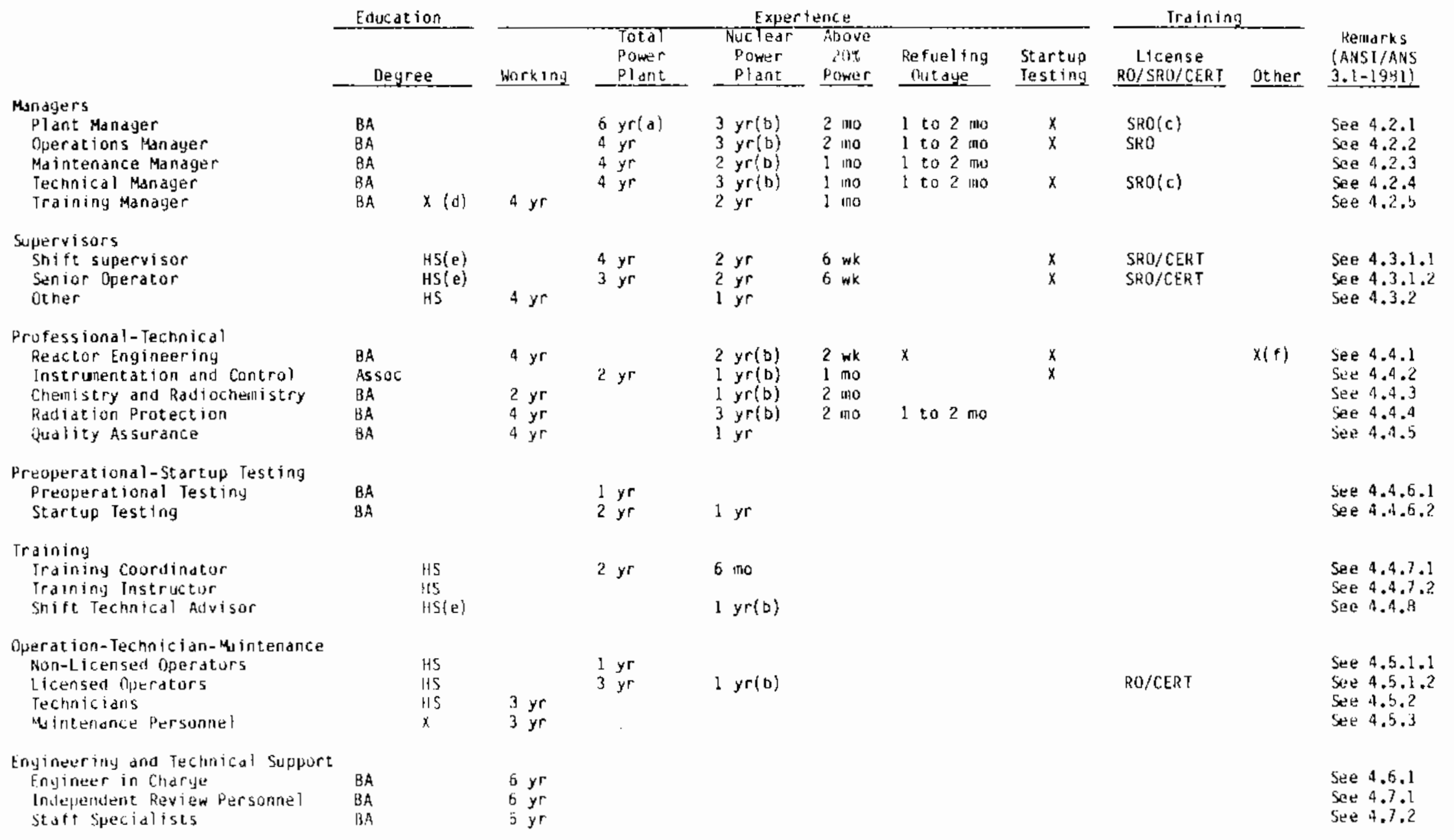

(a) The plant manayer sndll have a minimum of four years of supervisory or manayenterit experience.

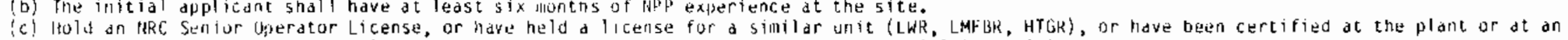
appropriate $5 i$ inulatur $(5.5 .1 .6)$ in accoriance with 5.2 .1 .3 . Also, as required by 5.3 .1 and 5.4 .

(d) Courses in ealudation and techaical subjecis.

(e) Hijn schuol diplalla plus the equivalence of thirty to sixty semester hours of college-level technical education.

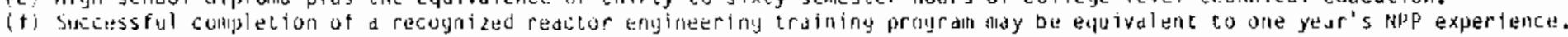


- Maintenance personnel are required to have a journeyman level education and three years' work experience in one or more crafts.

- Instrument and control (I\&C) technicians are to possess an associate degree in engineering or related science and two years' power plant experience, one year's NPP experience and one month's nuclear experience at greater than $20 \%$ power.

- The maintenance manager is required to have a bachelors degree in engineering or related sciences, four years' power plant experience, two years' nuclear experience, one month's nuclear experience at greater than $20 \%$ power, and one to two months' nuclear refueling experience.

- Technicians (those responsible for the performing of tests, calibrations, inspections, surveys, and repairs of instruments and controls and equipment) need a high school diploma or need to have passed the General Education Development (GED) test and three years' working experience in their specialty.

For maintenance personnel and technicians, ANSI/ANS 3.1-1981 also states that they

"shall have demonstrated their ability to perform assigned tasks and their knowledge of the significance of these tasks on plant operation."

Each NPP is to establish a training program to provide for qualified personnel to operate and maintain the facility. All personnel at the plant are to receive training in the following areas commensurate with their job duties (ANSI/ANS 3.1):

- general description of plant and facilities

- job-related procedures and instructions

- radiological health and safety program

- station emergency plans

- industrial safety program

- fire protection program

- security progran

- quality assurance program. 
Specialized training shall also be provided based on the analysis of the individuals' lack of experience and knowledge in relation to their assigned functions. For technicians and maintenance mechanics, the standard states that the specialized training program shall include the following:

- information on applicable administrative controls

- information on special complex systems and components

- demonstration of performance capability. No specific criteria are indicated for either the instrument and control personne? or maintenance managers.

Once an individual has satisfied the appropriate education and experience requirements and has passed "an examination of sufficient difficulty covering the previously listed areas," he can then be assigned to work independently at the facility (par 5.4, pp. 14-15).

Retraining shall be provided annually and should include information on the changes in the facility, in the procedures, in government regulations, and in quality assurance requirements. Industry operating experience, licensee event reports (LERs), and personnel errors are also to be reviewed as they apply to the individual's specialty area.

\subsubsection{ASME/AWS Welding Requirements}

Because of the critical safety nature of the welding operations, the NRC requires that all welds on pressure-retaining components and systems be performed according to requirements of Chapter IX of the American Society of Mechanical Engineers (ASME) Boiler and Pressure Vessel Code. All welds on structures and buildings are done according to the American Weiding Snciety (AWS) structural welding code. The NRC, the ASME Code and the AWS Code require that all welding procedures and welders be qualified prior to use in production welding.

The ASME Code requires critical pipe welds to be nondestructively examined using liquid penetrant, magnetic particle, ultrasonic or radiographic examination, depending on the pipe classification. The weld quality is evaluated according to criteria specified in the Code. NRC resident inspectors periodically inspect the completed welds, the welding procedures and welder qualifications. 


\section{2.? CURRENT UTILITY PRACTICES/CONCERNS}

One of the key issues in maintaining the safety of NPPs is the quality of the maintenance personnel. This opinion was expressed at all plants we contacted. The major safety-related problem areas concern personnel turnover, the selection methods used in hiring maintenance personnel, the lack of standard grade/job classifications, and the difficulty of verifying qualifications.

\subsubsection{Maintenance Staff Turnover}

Several utility and plant managers indicater a concern for assuring the continued quality of their maintenance personnel. The changing manpower situation was identified as a major reason for their concern and the impetus for changing their employee selection methods and for developing new training programs.

During the last five to eight years, many plants have found turnover among their maintenance personnel to be a problem. At a recent round table discussion on this subject, several managers indicated that in the past a manager dealt with the same people for years (Rittenhouse 1982). Today, many utility organizations appear to be constantly attempting to qualify new people because of high attrition rates. Many reasons were given for this changing manpower situation:

- Many skilled nuclear maintenance personnel are reaching retirement age.

- Fewer applicants have had any technical training provided by the military or other industries.

- Many qualified personnel want to move into higher positions of authority and benefits.

- Many qualified personnel want to relocate both geographically and out of the nuclear industry.

The movement of qualified and experienced personnel out of the maintenance department to other plants (both nuclear and fossil), to other positions within the utility, or to jobs outside the nuclear industry has been a significant problein for some plants. These probiems are expected to increase as new plants 
now under construction hegin to staff up and come on-line. The opportunities exist for the more experienced, qualified, and motivated individuals to transfer to these new plants in positions of greater authority and pay. An example of this is found in the staffing of Watts Bar 1 and 2 (scheduled to go critical in 1984 and 1985, respectively). The FSAR (Watts 8ar 1982) states that

"...experienced journeymen will predominantly be transfers from other TVA generating plants and installations."

In a recent study of nuclear power industry manpower requirements, an additional 4400 workers were estimated to be needed by 1991 to fill new maintenance positions and another 6300 needed as replacements (Johnson 1982). For comparison, the 1981 maintenance staffing level was 5700. Consequently, providing qualified individuals to fill these current and projected staff positions has become one of the major justifications for the extensive training programs being implemented at many utilities. (See Chapter 3.0 for a more detailed discussion of training activities.)

\subsubsection{Selection Dualifications}

The principal method of filling a vacancy or staffing a new plant's maintenance department has been to select the most qualified and experienced individual as possible. This appears to still be the most comenon way of acquiring new staff members for existing plants, particulariy for those utilities with no extensive training program. Because an apprenticeship program can take up to four or more years to qualify an individual, many of the maintenance managers we contacted are searching for position-specific qualified individuals. As a result, most plants operate with many unfilled positions. The Institute of Nuclear Power Operations (INPO) has identified a vacancy rate of $10.8 \%$ for skilled craft workers in NPPs (INPO 1981). For I\&C technicians INPO found the rate to be almost $15 \%$ industry wide.

To counter problems from high vacancy and attrition rates, many of the larger utilities have begun to hire new maintenance staff based on their potential for further training. This approach, however, requires that an appropriate training program be available to provide the necessary education and experience. 
An example of the selection qualifications used within the nuclear plant maintenance departments is shown in Table 2.2. As the table shows, the amount of experience required of new employees varies considerably, from some experience to 8 to 10 years. At other plants we contacted, minimum employment requirements are a high school diploma, no previous experience, and a potential for further training. Applicants were judged on such factors as their personality, mechanical aptitude, and previous specialty training.

The actual screening and selection process for maintenance personnel generally consists of two or three stages:

- application form

- skills' demonstration

- personal interview.

The initial stage at all plants we examined involves some type of job application form. The primary information obtained from this form includes educational background, work histories, experience, and reference sources. At nine plants we specifically asked how they verified the applicant's information. Only four indicated they ran any kind of reference check and only one stated they requested education transcripts.

The second stage of the maintenance personnel screening/selection process can, for certain applicants, involve an employment test. Welders in particular are required, if they are to work on pressure-retaining components, to pass a welding skills-proficiency test. In some cases, this test is administered by a local consultant or technical school. IRC technicians are also given a test. In this case it is usually an aptitude test to evaluate their analytical, numerical, and verbal skills, and mechanical aptitude and knowiedge in their specialty. Some plants use standard personality tests and aptitude tests for all applicants. With more organizations developing training programs, these testing methods are increasingly being used for all applicants (to avoid any difficulties with unions and the appearance of discrimination, according to one individual we spoke with). These tests can help the personnel department to properly screen likely candidates for the training programs. 
TABLE 2.2. Maintenance Staff Selection Requirements(a)

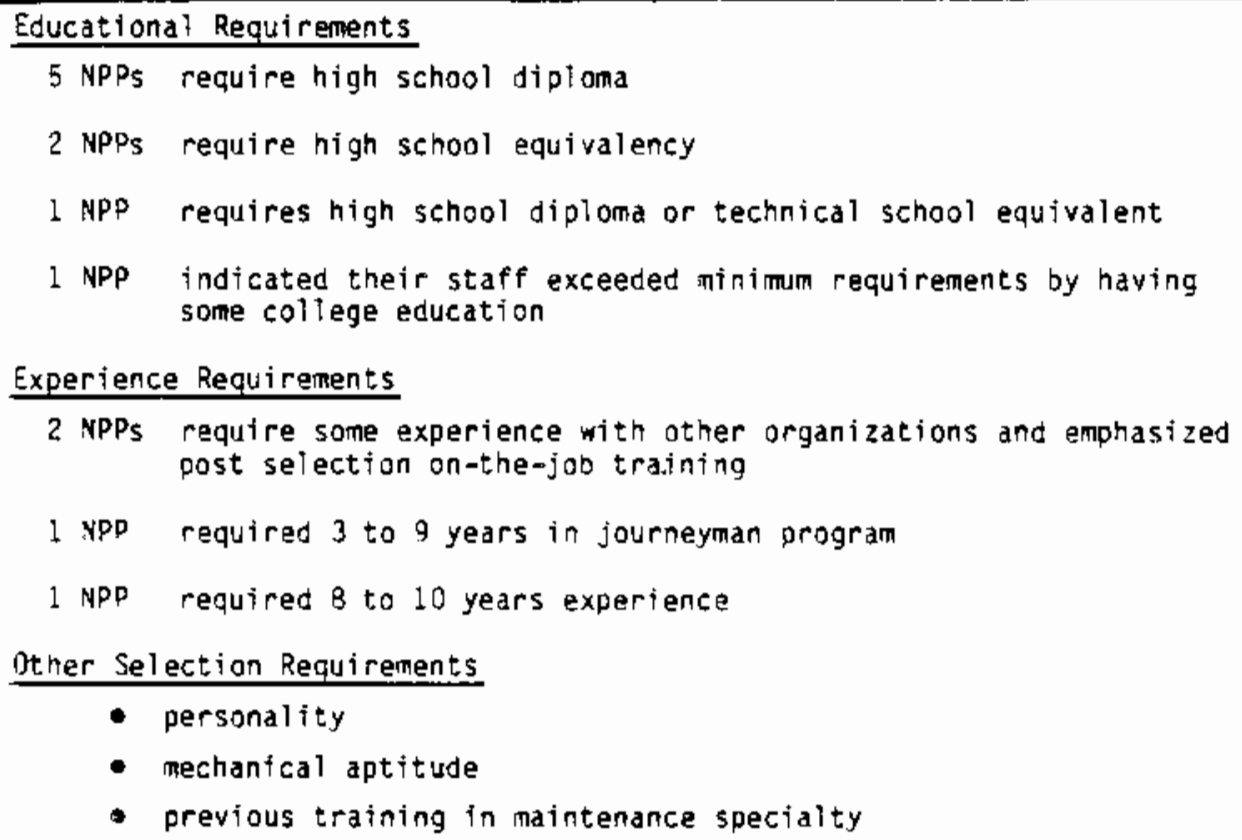

(a) Based on the response of nine NPPS.

The final stage at ali plants is the personal interview and usually involves the maintenance manager and the appropriate foreman. Most managers we spoke with use the interview to examine the personal characteristics of the applicant, to evaluate their past work experiences and to assess their background knowledge. For many plants the personal interview, along with the mandatory initial application form, constitutes the primary selection process for maintenance personnel - particularly maintenace mechanics. Stages one and three seem to be the focus where minimal training programs exist and where the management philosophy is to select only journeymen-level experienced candidates.

\subsubsection{Grade/Job Classification}

Maintenance personnel can he divided into three basic grade classifications:

- hetper

- assistant

- technician. 
Of these, only the technician can operate independently or supervise a team in repairing plant components and systems. Both the helper and assistant must be fully supervised. The helper is usually a young high-school graduate (or equivalent degree) with no prior experience. The helper's job is to assist by performing many of the more menial tasks, such as cleaning up and running errands.

The assistant usually is an individual enrolled in an apprenticeship or apprenticeship-type program. A significant portion of the assistant's course requirements is on-the-job training. An assistant's specific qualifications vary from utility to utility, plant to plant, and from union to non-union organizations. After the assistant successfully completes the program, he/she is certified as a journeyman by the union or as a journeyman-level technician by the utility. This then satisfies the "journeyman level" education requirement of ANSI/ANS 3.1-1981. After fulfilling the other basic educational and experience requirements, the individual can be classified as a technician to work independently at the facility.

Unlike grade classifications, NPP job classifications, such as maintenance electricians, welders, mechanics, etc., are not standard across the industry. This lack of standardization creates problems in hiring, testing, training, and promoting personnel. Each utility organization has developed its own sets of job classifications and performance evaluation criteria. This not only makes it difficult for integrating experienced new hires into the maintenance organization without retraining, it also affects the efficient use of maintenance service organizations.

Many individuals we contacted stated that such standard job classifications are necessary for the development of standardized maintenance organizations. To address this problem, INP0 has recently issued a report on guidelines for the qualification of electrical and mechanical maintenance personnel and I\&C technicians (INPO 1981). The report's stated purpose is to provide a program that will assist in developing a maintenance team with the knowledge and skills necessary for the safe, reliable, and efficient operation of a nuclear plant. In addition to qualification requirements, the guidelines also include training, trainee evaluation, and continuing education requirements. Although INPO does use these guidelines in their plant evaluations (INP0 1982), 
their use by the utilities is strictly voluntary. Presently, the guidelines are general. INPO intends to provide additional guidance based on their job and task analysis study effort, which is to be completed in 1984 .

\subsubsection{Maintenance Personnel Qualifications Assurance}

Verifying the maintenance staff qualifications is an important aspect of the NPP qualification assurance operation. The ANSI/ANS 3.1-1981 standard requires auditable records of the qualifications, experience, training, and retraining for each member of the plant organization. These records are "to be maintained for at least five years or as long as the person performs work in the job category described in this standard, whichever is shorter" (ANSI/ANS 3.1-1981). Also, certain records associated with ASME activities are to be maintained according to ANSI/ASME NOA-1-1979.

The NRC's inspection programs are based on two documents, the safety analysis report (SAR) and the safety evaluation report (SER) (DeYoung 1983). In the SAR the licensee formally commits to technical and quality assurance requirements. The NRC staff reviews the SARs to assure, in part, that required levels of technical and qualification assurance standards will be achieved. Their review is documented in the SER.

In our review of the FSARs for eight plants scheduled to come on-line within the next one to four years, we found four different versions of Regulatory Guide 1.8 referenced. A breakdown of the FSAR personnel qualifications references is presented in Table 2.3. Currently, the only official version of Reg. Guide 1.8 is dated September 1975, reissued May 1977. As the table shows, only two of the eight plants reviewed referenced the 1975 or 1977 official versions of Reg. Guide 1.8. We also found in the FSARs two verstions of ANSI/ANS 3.1 and two versions of ANSI N18.1 referenced. This use of various references for plant personnel qualifications indicates obvious confusion on the part of plant staff and possible lack of attention that the NRC licensing review staff has given to the documentation and subject of qualifications.

At the base of the actual inspection and qualification assurance programs are the measures taken by the crafts. The apprenticeship training programs are controlled by federal and state regulations. Revisions to the programs must be 
TABLE 2.3. FSAR Qualification Requirements - Referenced Standards/Regulations

\begin{tabular}{|c|c|c|c|}
\hline Plant & Standard & Regulation & Other \\
\hline $\begin{array}{l}\text { Marble Hill } \\
(1987)\end{array}$ & ANS1/ANS $3.1-1981$ & Reg. Guide 1.8 & $\begin{array}{l}\text { Case-by-case } \\
\text { review, use of } \\
\text { INPO job task } \\
\text { analysis }\end{array}$ \\
\hline $\begin{array}{l}\text { Hope Creex - } 1 \\
(1986)\end{array}$ & AKSI/ANS 3.1 & Reg. Guide 1.8 & $\begin{array}{l}\text { Case-by-case } \\
\text { review }\end{array}$ \\
\hline $\begin{array}{l}\text { Nine wi le } \\
\text { Point (2) } \\
(1986)\end{array}$ & ANS I N18.1 - 1978 & Reg. Guide 1.8 & -- \\
\hline $\begin{array}{l}\text { Beaver } \\
\text { Valley } \Rightarrow 2 \\
(1986)\end{array}$ & AKSI N18.1 - 1971 & $\begin{array}{l}\text { Reg. Guide } 1.8 \\
(1975)\end{array}$ & $\rightarrow$ \\
\hline $\begin{array}{r}\text { Watts Rar } \\
(1984)\end{array}$ & ANSI N18.1 - 1971 & $\begin{array}{l}\text { Reg. Guide } 1.8 \\
\text { (Reg 1.8) }\end{array}$ & -- \\
\hline $\begin{array}{c}\text { Millstone } 3 \\
(1986)\end{array}$ & ANSI N18.1 - 197 I & $\begin{array}{l}\text { Reg. Guide } 1.8 \\
(1977)\end{array}$ & - \\
\hline $\begin{array}{l}\text { Midland } 1 \& 2 \\
\quad(1983-1984)\end{array}$ & ANSI $N 18.1$ & Reg. Gride 1.3 & -- \\
\hline $\begin{array}{l}\text { Byron/ } \\
\text { Bratdwood } \\
\quad(1984-1985)\end{array}$ & ANSI N18.I - 1971 & $\ldots$ & -- \\
\hline (a) Plants sche & to cone on line in & and 1985. & \\
\hline
\end{tabular}

approved by the union, the utility, and the state department of labor. However, recent allegations have indicated that in certain cases individuals have been able to bypass the apprenticeship program and purchase union membership or "books" identifying them as qualified journeyman (Hatch 1983). At a hearing of the Labor and Human Resources Committee in late June, 1983, witnesses testified that illegal journeyman book buying has been occurring for several years in the boilermaker trade. One witness estimated that 50 to $60 \%$ of the workforce at Unit 1 of Three Mile Isiand were unqualified to hold journeyman books. These statements and allegations that a widespread practice exists of "stand-ins" taking weiding tests for illegal card holders lead the committee to request the NRC and the Justice Department to investigate these activities.

The NRC Office of Inspection and Enforcement indicated that all regions have taken action to review welder qualifications and have found no indication 
of welder "stand-in" during these inspections (DeYoung 1983). Two of the five regions estimate they annually review 100 to 150 welder qualifications and witness about $10 \%$ of these taking their tests. In only one case had a stand-in been verified. This was at Monticello and "appropriate action was taken" (welder site access revoked) (DeYoung 1983). Further hearings are scheduled on this subject (August 2, 1983) partly because unqualified individuals being employed at NPPs is a concern to public safety.

In another effort for qualification assurance, the industry has initiated a series of inspectional evaluations through INPO. These evaluations are conducted about every 15 months at operating plants and about every 18 months at plants under construction.

The plant/utility management and the maintenance supervisor make the actual judgment of whether an individual is qualified to work independently at a NPP. Verifying the qualifications of new hires is difficult for several reasons:

- Job classifications and duties vary both within and outside the nuclear industry for the same specialty craft.

- Training and education, both in quality and depth, vary.

- Documentation methods and the problems of acquiring such docurnentation vary.

The increased use of extensive in-house job-training programs and their associated tocumentation should reduce some of these problems.

According to the maintenance managers, the main question of qualifications currently revolves around those critical but infrequent functions, such as removing the steam generator heart. For this, retraining and the use of mockups are advocated to bring the staff up to speed.

\subsection{SUMMARY OF MAIN PERSONNEL QIJALIFICATIONS ISSUES}

The current NRC regulations and standards provide only a general set of maintenance qualification requirements for evaluating an individual. An assessinent of these maintenance personnel qualifications has identified two 
main safety-related problem areas that need to be analyzed before recomendation can be developed on potential improvements to these qualifications requirements and selection methods. The main problem areas are as follows:

1. Verifying and assuring that the plants are staffed with qualified maintenance personnel are difficult because of the following:

- the lack of standard job classifications, which creates problems in hiring, testing, training and promoting personnel

- the wide variance in the quality and content of the training and educational background that maintenance personnel receive

- the variance in the methods of documenting skills, knowledge and ability of maintenance personnel and the difficulty in acquiring such documentation.

2. The lack of specific regulatory guidance on necessary basic skills, knowledge and abilities (e.g., journeyman-level education requirement for maintenance mechanics) has lead to inconsistent interpretation of existing qualification requirements. This lack has resulted in the following:

- variations in the selection and screening criteria of new empl oyees

- no standard, consistent basis for developing maintenance training programs. 


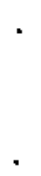




\subsection{MAINTENANCE TRAINING.}

This chapter summarizes the NRC's regulations on maintenance training and problems with that training in NPPS. The information presented here is based on visits to plant sites, interviews with plant personnel, and a literature review. Wide variations exist in the quality of training for maintenance personnel at individual power plants. In this study we examined many of these training programs.

\subsection{TRAINING AND EDUCATION}

Training and education have important distinctions. The purpose of education is to prepare people to deal with a wide variety of problems spanning many possible occupational fields. It is open-ended and broadly based. Training is intended to develop skill and proficiency for specific jobs and is the prinary way to qualify personnel to perform on the job. Inadequate human performance in conducting NPP maintenance can have significant and far-reaching consequences (for example, TMI, Ginna, and Salem). Trajning is one of the most important ways to assure proper performance.

\section{3.? NRC REGIJLATORY GUIDANCE}

In a study of NPP staffing performed for the NRC over two years ago, Wegner (1980) found that the only eligibility/qualification requirements issued by the NRC for maintenance repairmen in NPPs were three years in one or more crafts and a "high degree of manual dexterity and ability," plus the capability to learn. Technicians (a) were required to have two years' working experience in their specialty and one year of related training. No specific training or

(a) Plant personnel responsible for the maintenance of instruments and controls are generally termed "technicians." They have their own section, which is sometimes organized inder the Maintenance Superintendent and sometimes under the Technical Services Superintendent. In this report we are using the term "maintenance personnel" to include I\&C technicians. 
requalification requirements were given for technicians or maintenance repairmen. Wegner's findings were based on a review of existing NRC regulations and guidance, including 10 CFR 50; Reg. Guide 1.8, September 1975, reissued May 1977; and ANSI N18.1-1971, which Reg. Guide 1.8 endorsed.

Since Wegner's study, the ANSI and the ANS have re-issued their standard on Selection, Qualification, and Training for Personnel for Nuclear Power Plants twice, with the latest version being ANSI/ANS-3.1-1981. Two "For Comment" revisions of Reg. Guide 1.8, dated February 1979 and September 1980, have been issued. The Fehruary 1979 version endorsed ANSI/ANS-31.1-1979. The September 1980 version endorses a draft ANSI/ANS 3.1 dated December 6, 1979, which has since been superceded by the official 1981 standard. If Reg. Guide 1.8 is eventually issued of ficially and if it endorses ANSI/ANS-3.1-1981, maintenance training would be addressed as follows:

\footnotetext{
"Technicians and maintenance personnel shall be trained by on-the-job training; by participation in initial calibration, testing, and equipment acceptance programs; or by related technical training to meet the qualifications set forth in $4.5^{\prime \prime}$ (par. 5.3.4, pg. 14).
}

The qualification standards set forth in paragraph 4.5 of ANSI/ANS-3.1-1981 are for journeymen-level personnel. As stated previously, those standards are very general. Apparently, the authors of the standard felt that stipulating journeyman level as the "education" requirement was sufficiently descriptive and would adequately define training requirements. However, as the next section discusses, apprentice training leading to the journeyman level may vary considerably in its content and quality. Therefore, because of such variations there is little assurance of consistent qualifications across the inctustry at the journeyman level.

The 1981 version of ANSI/ANS-3.1 expands on the training requirements of the previous version of this standard by stating the following:

"A training program shall be provided for job functions that could affect the quality of structures, systems, and components important to safety. The program shall include applicable administrative controls, special complex system and component instruction, and demonstrated performance capability. The special training above the 
journeyman level of technician and maintenance personnel shall be based on a task analysis of the individual's assigned functions" (par. 5.3.4, pg. 14).

Therefore, ANSI/ANS-3.1-1981 requires task analysis of maintenance functions to determine special training requirements above journeyman level for functions that "...could affect the quality of structures, [etc.] important to safety." If NRC endorses ANSI/ANS-3.1-1981 in its Tatest version of Reg. Guide 1.8, amplification of this paragraph of the standard may well be desirable.

In addition to the above, maintenance personnel will needs general employee training (ANSI/ANS 3.1-1981):

All persons regularly employed in the nuclear power plant shall be trained in the following areas commensurate with their job duties (ANSI/ANS 3.1-1981):

- General Description of Plant and Facilities

- Job Related Procedures and Instructions

- Radiological Health and Safety Program

- Station Emergency Plans

- Industrial Safety Program

- Fire Protection Program

- Security Program

- Quality Assurance Program".

The standard goes on to address temporary personnel, stating that,

"Temporary maintenance and service personnel shall be trained also in the areas listed in the preceding paragraph to the extent necessary to assure safe execution of their duties" (par. 5.4, pg. 14-15).

For temporary personnel this requirement is the same as previous versions of this standard, but the following paragraph for the standard is an important addition:

"The individual's understanding of the information provided by this program shall be evaluated by administering an examination of sufficient difficulty covering the previously listed areas to ensure the individual has sufficient knowledge to work independently at the facility. Individuals who do not pass this examination shal 1 not be permitted inside the protected area without a full time escort" (par. 5.4, pg. 14-15). 
The standard recognizes the importance of considering training in determining plant manpower requirements, stating that,

"In determining the staff complement, the facility management shall recognize the important relationship the training program has to the maintenance of operational safety by a) providing experienced and knowledgeable personnel to develop and audit the training program as well as serve as training program instructors; and b) provide sufficient personnel in classifications to permit training and requalification work" (par. 5.5, pg. 15).

Another important aspect of the 1981 standard is that it addresses the need for evaluating the training program and requires that evaluation be conducted, "by persons other than those directly responsible for the training" (par. 5.5, pg. 15). Evaluations are required annually and must cover training content, quality, appropriateness, exam difficulty, and grading.

Of particular note is the standard's stipulation that job/task analysis (J/TA) be used to establish the training program. When it comes to maintenance, however, the extent to which J/TA must be used is not clear.

The 1981 version of ANSI/ANS-3.1 is a more comprehensive and detailed treatment of maintenance training than previous versions. The current situation regarding Reg. Guide 1.8 is confusing, however, and needs to be clarified. Currently, the only official version of Reg. Guide 1.8 (September 1975, reissued May 1977) endorses ANSI N18.1-1971, which is two versions removed from the current ANSI/ANS standard (ANSI/ANS 3.1-1981). In addition, the most current "For Comment" issue of Reg. Gllide 1.8 endorses a pre-ANSI/ANS 3.1-1981 draft standard (ANSI/ANS 3.1-1979). These relationships are shown in Figure 3.1.

Training information that utilities need to address in their Preliminary Safety Analysis Reports (PSARs) and FSARs is contained in Section 13.2 of the Standard Review Plan (SRP) (NUREG-0900). The SRP is far more general than ANSI/ANS-3.1-1981 concerning training, and maintenance is not addressed specifically but put under "non-licensed plant staff" (par 13.2.2). Reg. Guide 1.8 and ANSI/ANS-3.1 are referenced in the SRP, and acceptance criteria in the SRP include training in accordance with Sections 5.1., 5.3, 5.4, and 5.5 of ANSI/ANS-3.1, as endorsed by Reg. Guide 1.8. We believe maintenance should be addressed specifically in the SRP to assure it gets the emphasis it deserves in the PSAR/FSAR. 


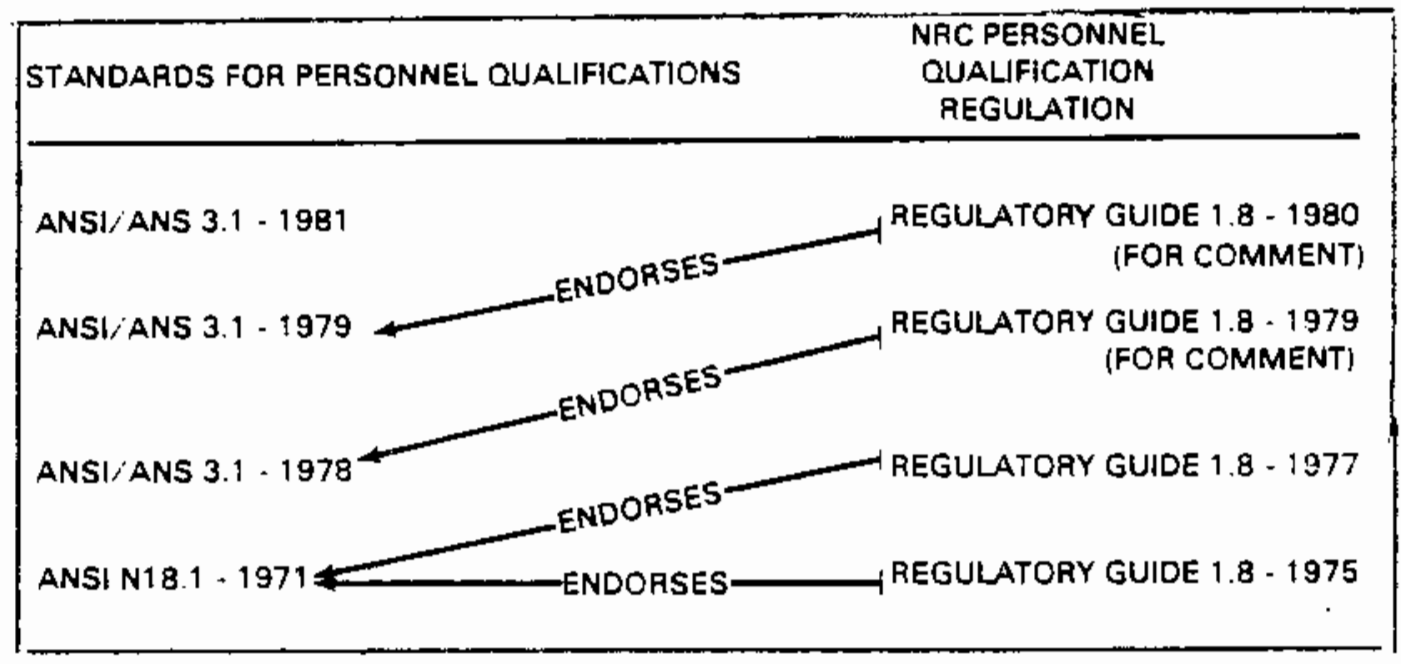

FIGURE 3.1. Maintenance Personnel Standards and Regutations

In summary, current NRC guidance on training of maintenance personnel is in a state of transition. Some documents are outdated and endorse outdated standards. Proposed documents also endorse outdated standards. Guidance to the industry is therefore incomplete and, in many cases, too general to assure that adequate training programs are being conducted across the industry.

\subsection{PROBLEMS IN NPP MAINTENANCE TRAINING}

Although maintenance training is important in the nuclear industry, generally very little emphasis has been placed on it, especially compared to the emphasis placed on operator training. Any maintenance training tends to be handled unsystematically, with little or no attention to instructional technologies that have long been practiced successfully in other fields (notably, the military). Basically, three interrelated problems are associated with maintenance training in the nuclear industry:

1. As discussed, NRC regulatory guidance is incomplete and too genera1 to assure that adequate training programs are being conducted across the industry. 
2. Utilities generally have placed too little emphasis on maintenance training, resulting in both inadequate resources to apply to such training and the lack of an integrated approach to maintenance training.

3. NPP maintenance training programs are generally inadequate, lacking, among other things, a formal method to determine training needs, to evaluate the effectiveness of the training program, and to upgrade/ update the program as required. Of particular concern is the lack of available time for maintenance personnel to devote to training.

\subsubsection{Utility Management of Training}

NRC emphasis on training has, until very recently, been directed at licensed operator training. The NRC has not placed the same emphasis on maintenance training. Existing NPP maintenance training programs are a variable mix of the following training practices:

- on-the-job training

- structured self-study courses

- vendor training programs provided on- and off-site

- in-house training organization programs.

The emphasis in training programs varies from utility to utility; however, the general findings of a recent study are that $83 \%$ of electricians, $71 \%$ of mechanical personnel and $46 \%$ of the I\&C personnel expressed dissatisfaction with training efforts (Seninara \& Parsons 1981). Because most utilities do not give maintenance training high priority, resources to apply to such training are generally inadequate. The resources required for a sound training program include the following:

- available time for maintenance personnel to devote to training (a factor that must be considered in planning of maintenance manpower requirements)

- qualified training and administrative staff

- training facilities and equipment, including training aids

- training materials (e.g., nperating and maintenance manuals, vendor equipment manuals, plant maintenance procedures, general maintenance reference documents, plant systein descriptions, etc.) 
- sufficient funding to support the training, both in-house and hy contract.

If any of these resources are not available, the quality of the training programs will be affected. Problems in this area are discussed in the next section.

In our interviews with utility and power plant personnel conducted in 1982 and continuing this year, we are finding a greater awareness of the importance of maintenance training and, in some cases, a considerable investment in it. However, training management varies greatly among utilities. For example, one utility that we visited recently has invested about $\$ 30 \mathrm{million}$ in a large, well-equipped training facility and claims to spend $\$ 10 \mathrm{million}$ per year on maintenance training. At the other end of the range, another utility that we visited confines its maintenance training to on-the-job training (0JT) and a five-day orientation course on safety systems for maintenance personnel (other maintenance training is accomplished on a one-time basis for special jobs or newly acquired equipment).

The fact that many plants are unionized complicates the issue of maintenance training. Trade unions establish their own apprentice training programs for their members. Standards for such programs are promulgated by the Department of Labor (DOL) under Title 29, Part 29 of the Code of Federal Regulations (20 CFR 29). Unionized plants that to want to provide additional training for their journeymen workers must negotiate such training with the union.

Utilities can work with unions to set up apprentice training programs that meet both union standards (which must be in conformance with 29 CFR 29) and plant needs. This is the approach being used by one utility we visited. A Washington State DOL representative we interviewed considered this approach to be the most desirable since apprentice training programs are not of uniform quality or content. Therefore, hiring a journeyman craft worker does not guarantee an adequate level of plant-specific skill/knowledge proficiency for NPP maintenance. The DOL-trade union-utility connection is an area that will require careful consideration by the NRC before additional guidelines are implemented for maintenance personnel training in the nuclear industry. This subject will be addressed in greater detail in future reports. 
Finally, lack of utility emphasis on maintenance training results in a lack of direction in other aspects of maintenance areas that affect training. These other aspects include the following:

- policy on personnel selection criteria

- career paths and promotion policy

- performance appraisal

- policy on the use of job performance aids (JPAs) by maintenance personnel

- factors considered in determining maintenance manpower requirements. Structuring an adequate training program depends on integrating all of these aspects of maintenance with training. For example, a policy of selecting only journeymen workers would imply a very different approach to training than would a policy of selecting candidates directly out of high school. Our observations to date indicate that an increasing number of larger utilities are taking an integrated approach to structuring their maintenance training programs. One example of that approach is Arkansas Power and Light (AP\&L). At a recent (April 1983) FPRI-sponsored workshop on maintenance and in a Power Engineering magazine article (Evans 1983). AP\&L's Training Manager, Bob Evans, described the approach being used by AP\&L. The approach, called "Instructional Development System" (IDS), is a five-step process involving the following:

1. analyze system requirements

2. define education/training requirements

3. develop objectives and tests

4. plan, develop, and validate instruction

5. conduct and evaluate instruction.

As Fvans states, AP\&L's approach is borrowed partly from the U.S. Air Force's Instructional Systems Development (ISD) process (Air Force Manual (AFM) 50-2).

AP\&L'S IDS process includes a position task analysis system, a job candidate screening system, a "trainability test" designed to predict success in the training program, and performance reviews and supervisory ratings to assess training effectiveness. 
In summary, we found the following problems in the area of utility training management:

- lack of emphasis on maintenance training by utility management

- inadequate resources to apply to plant maintenance training

- lack of an integrated approach to maintenance training in many utilities.

\subsubsection{Plant Training Programs}

As stated in the preceding section, because maintenance training often is not given a high priority by utility management, resources for maintenance training at the plant are inadequate. Based on our interviews with plant personnel, the most important resource lacking at the plant level is time. Generally, training time is not considered when the number of maintenance personnel in a NPP is determined. As a result, training is conducted on a "time available" basis, rather than "as required". Personnel often are called out of classes to handle pressing maintenance problems. Also, many plants suffer from inadequately sized maintenance staffs in general (Badalamente et a) 1982). Under such circumstances, maintenance personnel may not receive the training they require.(a) Also, they may not receive retraining for skill maintenance.

Another problem related to plant staffing is the lack of enough qualified staff to develop, conduct, and administer maintenance training programs. The most common practice we found was to assign responsibility for maintenance training to a "veteran" of the maintenance workforce. This person generally had no previous training education or background. Several plants indicated that maintenance training managers received "supervisory" training, but only one indicated that training instruction had been received.

Maintenance training in power plants can take many forms. In-house training can consist of short courses covering one-time job requirements or new equipment, self-study programs, regularly scheduled classroom training covering maintenance fundamentals, and on-the-job training (0JT). In addition, many

(a) Note also, that as will be discussed in Chapter 4.0, maintenance is not usualiy conducted in shifts. Therefore, the concept of a "training shift" as used by licensed operators, is virtually unheard of in maintenance. 
plants bring in vendors to provide one-time classes or send their maintenance personnel to vendor facilities for specialized training. Some vendors provide very complete maintenance training courses in their modern, well-equipped facilities and also onsite courses. Plants may also sponsor community college courses for their personnel. Although we found a variety of training methods being used, the most common by far was OJT. It was our impression that plants tend to over-rely on OJT for maintenance training. Responsibility for overseeing OJT is generally assigned to the foreman. As Seminara and Parsons (1981) have pointed out, this approach has limitations. Foremen are busy with day-to-day maintenance activities and tend to let training matters slip. The foreman's busy schedule also contributes to a lack of proper documentation for OJT. To be effective, OJT should be a planned part of an integrated maintenance training program. As such, OJT should be administered by the training staff (even though the supervisor is responsible for ensuring that training is accomplished). These deficiencies in plant training staff undermine the value that could be realized from $0 \mathrm{JT}$.

Inadequate training staffs at the plant have also resulted in maintenance training being approached unsystematically. None of the plants we visited were using joh/task analysis ( $\mathrm{J} / \mathrm{TA}$ ) to determine maintenance training needs or a formal system for evaluating the effectiveness of their training. Next to the lack of maintenance staff time to devote to training, this lack of a systematic approach to training is the most significant problem we found.

One measure of a plant's emphasis on maintenance training is its investment in training facilities and equipment. Several plants we visited have invested in good maintenance facilities. However, appropriate maintenance training aids are generally lacking. The idea of "simulators" to train maintenance personnel has not caught on in the industry, although their use is common for operators. One nuclear steam supply system (NSSS) vendor we visited is marketing a computer-aided-instruction (CAI) system, but none of the plants we visited were using CAI in their maintenance training.

Another virtually universal problem in maintenance training is the lack of good training materials, especially lesson plans. Where lesson plans did exist, they consisted only of topical outlines of material to be covered. They 
did not contain measurable training objectives, the main points to be covered, or samples of behavior that could subsequently be tested for. The lack of good maintenance procedures (job performance aids--JPAs) also hinders training, since such JPAs could be used effectively in demonstration-performance type training. In addition, vendor technical documentation (e.g., equipment manuals) is often lacking, especially for secondary suppliers, and this hinders special, equipment-oriented training (see 8adalamente et al. 1983).

Finally, some maintenance managers we interviewed complained of inadequate budgets for maintenance training. Sending people offsite to vendor-run training facilities can be especially expensive, particularly where unions are involved. Funding requirements, in general, include on- and off-site vendor training, sponsored community college course work, and training at other utility's facilities.

Our analysis shows that plant maintenance training programs suffer from the following problems:

- inadequate plant training staff

- an overreliance and ineffective use of 0JT

- lack of a systems approach to develop maintenance training programs

- generally inadequate maintenance training aids, materials, and funding.

\subsection{SUMMARY OF MAINTENANCE TRAINING}

Section 306 of the 1983 waste Management Bi11 directs the NRC to:

"promulgate regulations or other appropriate commission regulatory guidance for the training and qualifications of civilian nuclear power plant operators, supervisors, technicians and other appropriate operating personnel" (Waste Management Bill 1983).

As they potentially relate to NPP maintenance personnel, the regulations or guidance shall establish instructional requirements for civilian nuclear power plant licensee personnel training programs. 
These regulations or regulatory guidance are to be promulgated within 12 months following the passage of the Waste Management Act. The NRC is also required to report to Congress within the 12-month period detailing their compliance actions.

The NRC action plan developed as a result of the TMI-2 accident (NUREG0660, NRC 1980) included under Task I.A.2 the objective to do the following:

"Increase the education, experience, and training requirements for operators, senior operators, supervisors, and other personnel...to substantially improve their capability to perform their duties" (I.A. 2-1).

The TMI Action Plan (TAP) makes specific reference to maintenance in requiring licensees to review and "justify the acceptability" of their training programs. Further, the TAP states that "a position task analysis" is the "preferred method" of fulfilling the requirement.

The TAP states that NRR will audit plants to

"...assure that training is formalized and structured, including the use of lesson $p$ lans, qualified instructors, qualified supervision of instructors, and proper conduct of training" (I.A. 2-4).

Suhstantial improvements are required in understanding and operating NPP maintenance training programs before the objectives of 306 or TAP Task I.A.2 can be realized. Plants are not using task analysis to determine maintenance training needs, and an audit of the type referred to above would find that most plant maintenance training programs are not "formalized and structured," do not include "the use of lesson plans," do not use "qualified instructors" or supervision thereof, and generally do not conduct "proper" training.

In our view, the first step for the NRC is to upgrade its training regulatory guidance to the industry. The next step is to develop detailed evaluation criteria for training audits, and the third step is for the staff of the office of Nuclear Reactor Regulation (NRR) to conduct carefully structured audits of NPP maintenance training programs. Future reports in this project will address each of these areas. 
Our preliminary assessment of NPP maintenance training operations identified several major safety-related areas that need to be analyzed or resolved before recommendations can be made on specific improvements to the NRC training regulations:

- lack of clarification of the current regulatory guidance on training to eliminate the endorsement and NPP use of outdated standards.

- the lack of job task analysis efforts in developing training programs

- the variations in maintenance training staff qualifications, the staff's instructional, nuclear and NPP-specific skills, knowledge, and abilities

- inconsistent documentation of maintenance training programs, their basis or justification, structure, content, instructors, lesson plans, and evaluation criteria of students, instructors and the program. 


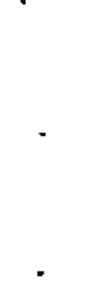




\subsection{MAINTENANCE SHIFTWORK}

Maintenance shiftwork concerns the scheduling of workshifts for maintenance personnel. The shift schedule determines the amount of maintenance coverage available to the NPP each 24-hour day. Because all safety systems require occasional repair and maintenance, the amount of maintenance coverage can affect the performance of safety systems.

Current maintenance shiftwork practices in the nuclear industry are poorly documented, and little information is available on the safety aspects of various forms of maintenance shiftwork coverage. Past studies involving shiftwork have invariably concentrated on shiftwork for NPP operators (Wond 1983) or shiftwork in related industries. This chapter will focus on identifying the available information and the information that needs to be sbtained to determine if the NRC should require around-the-clock maintenance coverage of NPPS. This focus includes discussions on NRC regulations and guidance, current industry practices, and problems with maintenance shiftwork.

\subsection{NRC REGIJLATION AND GUIDANCE.}

There is little NRC regulation and guidance concerning maintenance staffing levels during periods of normal NPP operation. The minimum level of maintenance coverage during NPP emergencies is given by NRC's NUREG-0654. Criteria for Preparations and Evaluations of Radiological Emergency Response Plans and Preparedness in Support of Nuclear Power Plants, November 1980. These minimum levels are given in Table 4.1. As the table indicates, the minimum level for maintenance personnel per shift is two - one mechanic and one electrician. Note that the footnote to the minimum staffing requirement in the table indicates that this requirement may be provided hy shift personnel assigned to other functions. The minimum on-shift requirement is supplemented by the requirement that an additional maintenance electrician and IsC technician be available within 30 minutes. An additional maintenance mechanic and electrician are to be available within 60 minutes. This November 1980 revision of NURE $1-0654$ is less stringent than the superseded February 1980 revisions, 
TABLE 4.1. Minimum Staffing Requirements for NRC Licensees for Nuclear Power Plant Emergencies (NUREG-0654 November 1980)

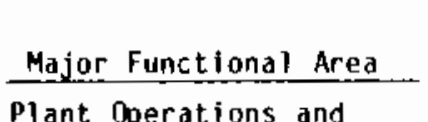

Plant Operations and

Assessment of

Operational Aspects

Emergency 0 irection and

Cnntrol (Emergency

\section{Notification/}

Communication (d)

in

Radiological Accident Assessment and Support of Operational Accident As ses sinent

\section{Plant System}

Englneering, Repair

and Corrective Actions

\begin{tabular}{|c|c|}
\hline Major Tasks & $\begin{array}{c}\text { Position Title } \\
\text { or Expertise }\end{array}$ \\
\hline- & $\begin{array}{l}\text { Shift Supervisor (SRO) } \\
\text { Shift Foreman (SRO) } \\
\text { Control Room Operators } \\
\text { Auxiltary Operators }\end{array}$ \\
\hline
\end{tabular}

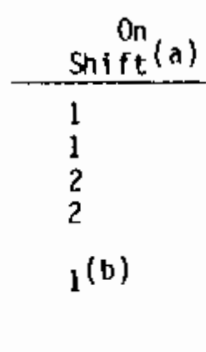

\begin{tabular}{cc} 
Capability for Additions \\
\hline 30 min & $\frac{60 \mathrm{~min}}{\mathrm{~m}}$ \\
\hline-- & -- \\
-- & -- \\
-- & --
\end{tabular}

Notify licensee, state,

local and federal personne

and maintaln cominumication

Emergency Operations

Facility (EOF) Director

off site Dose

As ses sment

Offsite Surveys

Onsite (out-of-plant)

In-plant surveys

Chemistry/Radi achemistry

Technical Support

Technical support

Repair and Corrective Actions
Shift Technical Advisor. Shift Supervisor or designated factlity

manager

(b)

1

Senior Manager

Sentor Health Physics

(HP) Expertise

HP Technicians

Rad/Chem Technicians

Shift Technical Advisor Core/Thermal Hydraulics Electrical

Mechanical

Mechanical maintenance/ Rad Waste Operator

Electrical Maintenance/ Instrument and Control (IRC) Technician

$-$

$--$

1

1

1

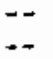

$1^{(b)}$

${ }_{1}^{(b)}$

$--$
1

2

1

$-$
2

1

1

$--$

1

1

1 


\section{TABLE 4.1. (contd)}

\section{Major Functional Area} Protective Actions (In-Plant)

Rescue Operations

and First-Aid

Site Access Control

and Personnel

Accountability

Radiation Protection:

a. Access Control

b. HP Coverage for repa1r,

corrective actions,

search and rescue first-

aid and firefighting

c. Personnel Monitoring

d. Dosimetry

\section{Position Title \\ or Expertise}

HP Technicians

$-$

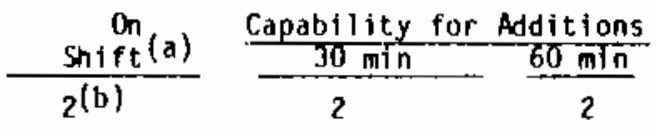

\section{Security, flrefighting} communications, personnel accnuntability

Ftre brigade Local support
per technical
specifications
$2^{(b)}$$\quad$ Local support

11

(a) For each unaffected nuclear unit in operation, maintaln at least one shift foreman, one control room operator and one auxiliary operator except that uofts sharing a control room may share a shift foreman if all functions are covered.

(h) May be provided by shift personnel assigned other functions.

(c) Overall direction of facility response to be assumed by emergency operations facility (EOF) director when all centers are fully manned. Director of minute-to-minute factlity operations remains with senior manager in technical support center or control room.

(d) May be performed by engineering aide to shift supervisor. 
which required that all additional maintenance personnel be available within 30 minutes. The reason for the change in the requirement was not clear. The regional NRC offices contacted could provide little or no information.

Little documentation outlines how each NPP meets the requirements set forth in NUREG-0654. The FSAR for each plant states the shift coverage for the operating crew but few FSARs state the shift coverage for the maintenance crew. When shift maintenance support is included in an FSAR, it is usually general. A typical entry is, "Craftsmen and technicians, as required, will be assigned to each operating shift for the purpose of providing maintenance support and surveillance testing in the areas of instrumentation and controls, and mechanical and electrical equipment." A few FSARs do give the maintenance shift coverage, but these tend to be exceptions to the format that most FSARs follow.

The guidelines for developing technical specifications normally do not decribe intended minimum maintenance shift coverage. For example, an excerpt from NUREG-0452, Standard Technical Specifications for Westinghouse Pressurized Water Reactors, Fall 1981, is given in Table 4.2. Note that maintenance personnel are not included in the format.

TABLF 4.2. Minimum Shift Crew Composition - Single Unit Facility (NUREG-0452 1981)

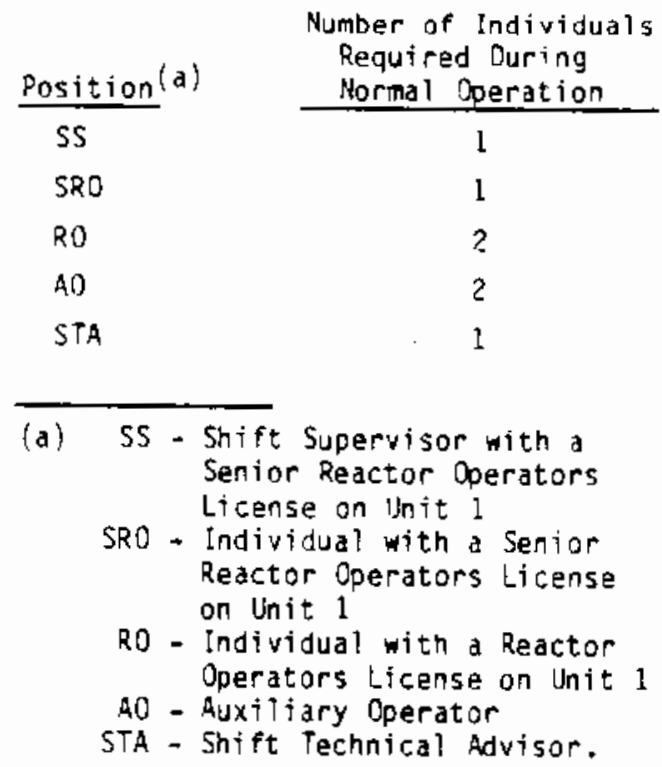




\subsection{CIJRRENT PRACTICES}

Information on maintenance shiftwork practice was obtained for over onethird of the operating nuclear power plants in the U.S. Most of these plants met the requirements of NUREG-0654 by maintaining a fixed-day-shift schedule with accommodations for coverage at other times. The fixed-day-shift typically consists of a "5-2" schedule. A "5-2" schedule refers to 5 days on, Monday through Friday, and two days off. The minimum maintenance coverage for the backshifts and weekends is usually provided by an I\&C technician and/or shift electrician with other maintenance personnel on call. The NUREG-0654 requirements for one maintenance mechanic on shift is often fulfilled by shift personnel assigned to other functions. If these other personnel are expected to do maintenance work, their assigned duties may suffer and/or the maintenance required may not get done.

Of the nuclear power plants surveyed, less than $30 \%$ use multiple maintenance shifts for nonoutage periods. Plants that do implement multiple maintenance shifts are on the average 3 years older than plants without shiftwork. As plants age, managers interviewed indicated that the workload increased sufficiently to justify additional staff for shiftwork.

The NPPS with multiple shifts vary in both their shift scheduling and in their maintenance staffing levels. The following is a sample of multiple shift maintenance schedules being used by different NPPs.

- skeleton maintenance crews on the backshifts, which are comprised of a few repairmen and technicians

- maintenance coverage on the night shift supplemented by nonpermanent hourly personnel

- three fixed shifts, with monthly rotating between days and afternoons, with schedules based on worker preference by seniority

- continuous maintenance coverage consisting of six 8-hour shifts, with weekly rotating

- continuous maintenance coverage consisting of five 12-hour shifts, with weekly rotating. 
Although a few plants have reported success with maintenance shiftwork, most plants continue to operate with one "5-2" fixed-day shift as noted previously. Many plants do not have multiple maintenance shifts primarily for two reasons: 1) perceived added expense, and 2) limited maintenance personnel. The added expense of maintenance shiftwork is considered by many utility corporate managers to be unjustifiably large. However, a cost-benefit analysis may show a cost savings from multiple maintenance shiftwork because of a more effective preventive maintenance program and more efficient use of maintenance personne1. Part of the reason for the limited maintenance shifts is the difficulty of finding qualified personnel to fill vacancies. The Institute for Nuclear Power Operations (INPO), in a survey of occupational employment in the nuclear power industry, found a vacancy rate of over $10 \%$ for skilled craft workers (INP0 1981).

Interviews with maintenance personnel revealed that more plants are adding additional maintenance shift coverage. In one plant, success with multiple shifts led to implementing shiftwork in another plant from the same utility. The interviews did not reveal any case of shiftwork being discontinued after it was implemented.

\subsection{MAINTENANCE SHIFTWORK PROBLEMS}

The literature revealed two main problems with maintenance shiftwork: insufficient maintenance coverage and the effect of shiftwork on personnel and their performance.

\subsubsection{Maintenance Coverage}

Several interviews indicated that the lack of maintenance personnel on backshifts results in operators (usually auxiliary equipment operators) making emergency repairs and adjustments that they are not trained to do. For example, one plant had equipment calibration problems because auxiliary equipment operators were adjusting the equipment during the backshifts when maintenance personnel were unavailable. The problem was compounded by a lack of guidelines as to what the operators could and could not do. This problem was eliminated by establishing skeleton maintenance crews on backshifts. 
One maintenance worker commented that long hours and large amounts of overtime resulted when his plant operated only a dayshift during nonoutage periods. Overtime resulted when people who were on call had to be brought in and when the dayshift crew had to be held into the evening to finish necessary maintenance work. The plant has since switched to operating five maintenance crews on 12-hour shifts. Crews rotate weekly through the dayshift, nightshift, training and offtime. This 12-hour shift had originally been used during outage periods only. Maintenance personnel generally like the new schedule because it results in more days off and it has substantially smoothed out the maintenance workload. Also, the amount of overtime worked by maintenance personnel has been reduced. The reduction in workload per person and in overtime can reduce fatigue and improve staff attitude, which can have a positive impact on plant safety.

Another plant that has implemented an 8-hour afternoon maintenance shift has found the results to be so advantageous that they are now considering implementing a night maintenance shift as well. This new schedule has reduced maintenance workload fluctuations and has been implemented with a minimum amount of coordination difficulties between shifts.

\subsubsection{Effect of Shiftwork on Personnel and Their Performance}

Although one type of safety problem related to inadequate maintenance coverage is alleviated by implementing shiftwork, a second type of safetyrelated problem emerges - the affect of shiftwork on maintenance personnel and on their performance.

The literature was extensively reviewed to determine the effect of shiftwork on maintenance workers' performance. However, this area has not been adequately studied. Folkard and Monk (1979) in their study state, "For a variety of reasons, such as union or management opposition and problems in finding appropriate neasures, there appear to be only six published studies that report relatively continuous, 24-hour real-life performance measures. Nevertheless, there is a fair agreement among these studies that a major impairment of performance occurs during the nightshift" (p. 483). 
The problems most frequently mentioned by managers concerned workers' different preferences for shifts, the scheduling process itself, and conflicts with nonwork activities. The managers also remarked that shiftwork causes problems with communication between shifts and maintaining tearmwork. The shift turnover procedures used to alleviate these problems for operating crews may be used to eliminate similar problems with maintenance shiftwork.

During one interview, a manager stated that the performance of maintenance personnel on the backshift deteriorates not from the physiological effects of shiftwork, but from a lack of supervision. The major problem mentioned by workers was the interference of the shift scherlule with family and social activities. A few mentioned that shift rotation was difficult to adjust to physically (e.g., sleep cycles). Typically workers preferred days, then afternoons, and then nights.

Table 4.3 summarizes the opinions of those interviewed on the advantages/ disadvantages of single vs. multiple shifts.

TABLE 4.3. Summary of Interview Dpinions of the Advantages/Disadvantages of Single vs. Multiple Shifts

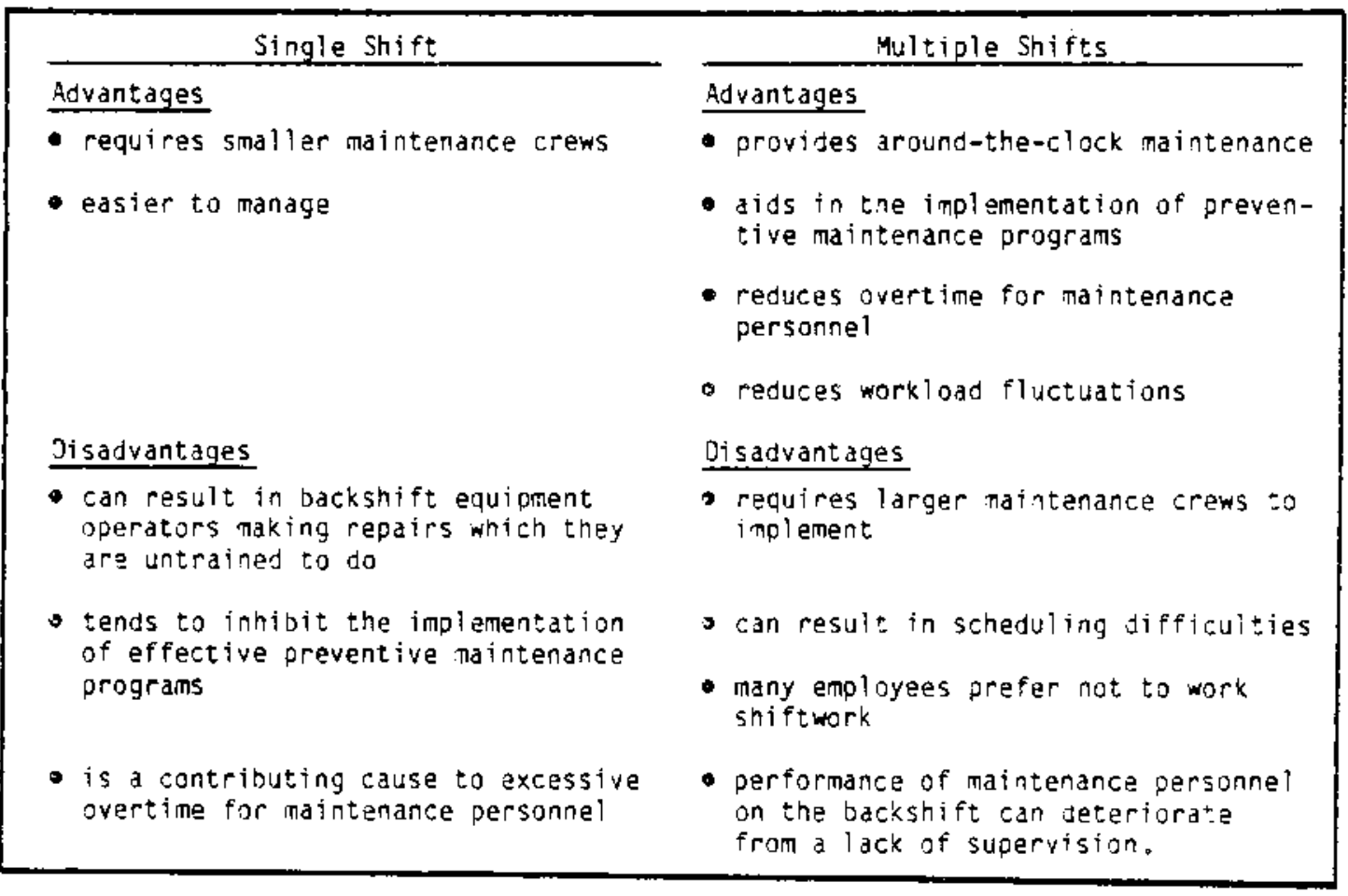




\subsection{SUMMARY OF MAINTENANCE SHIFTWORK ISSUES}

The preliminary review of maintenance shiftwork practices in NPPs reveals limited use and little documentation of maintenance shiftwork. Unlike the FSAR description of shift coverage for operators, the shift coverage description for maintenance personnel is generally incomplete.

Most NPPS schedule a single fixed-day maintenance shift for their nonoutage maintenance coverage. Plant management usually justifies a single maintenance shift by reduced maintenance costs, few personnel required, and less management supervision. Plants that have switched from single fixed-day maintenance coverage to day and backshift coverage report problems with the single fixed-day schedule. One frequently mentioned problem was that of auxiliary equipment operators attempting to make repairs when maintenance personnel are not on duty. Another problem with a single maintenance shift is that workload fluctuations result in large amounts of overtime for maintenance personnel.

To develop technically based regulations and requirements for maintenance shift coverage, the safety problems related to shiftwork must first be identified. Specifically, further information needs to be detailed in the following areas:

- Deterinine the number of situations affecting safety which are directly contributable to a lack of backshift maintenance coverage. This would be followed by detailed comparison of maintenance-related safety incidences for plants with and without maintenance shiftwork.

- Determine the amount of overtime worked hy maintenance personnel in plants with shiftwork compared to plants without shiftwork. This would determine if shiftwork is effective in reducing large amounts of overtine, which could adversely affect the safe performance of maintenance activities. 
- Compare the efficiency and effectiveness of maintenance programs for plants with and without shiftwork. Particular emphasis would be placed on the comparison of preventive maintenance programs. This would determine what role, if any, shiftwork has in enhancing the preventive maintenance programs already in existence at NPPS.

Studies in these areas would reveal safety-related problems and would provide information for making recommendations on regulation. 


\subsection{OVERTIME FOR MAINTENANCE STAFF}

Long work hours can affect performance and safety through increased fatigue. Work hours include both regularly scheduled work hours and overtime. This chapter deals specifically with overtime. The major areas discussed include a short comparison of federal regulations and policy on overtime, current industry practices for overtime, major problem areas related to overtime, and initial conclusions and recommendations based on our efforts thus far in this task.

\subsection{NRC POLICY ON OVERTIME}

The most recent NRC policy on NPP staff working hours is contained in Generic Letter 82-12 of June 15, 1982. This same policy statement was published in the June 1, 1982 Federal Register, 47 CFR 23 836. NPP licensees are directed to adhere to the following guidelines:

a. "An infividual should not be permitted to work more than 16 hours straight (excluding shift turnover time).

b. An individual should not be permitted to work more than 16 hours in any 24-hour period, nor more than 24 hours in any 48 -hour period, nor more than 72 hours in any seven-day period (all excluding shift turnover time).

c. A break of at least eight hours should be allowed between work periods (including shift turnover time).

d. Except during extended shutdown periods, the use of overtime should be considered on an individual basis and not for the entire staff on a shift."

These guidelines are incorporated in the revision of Regulatory Guide 1.33, "Quality Assurance Progran Requirements (Operation)."

The federal government aiso sets guidelines for hours of work in other industrial sectors. The following paragraphs compare three safety-related industries' regulations with the nuclear industry's regulations. Table 5.1 summarizes the working hours in these four industries. The transportation 
TABLE 5,1. Summary of Federal Guidelines and Regulations on Working Hours in Four Industries

\begin{tabular}{|c|c|c|c|c|}
\hline & \multicolumn{4}{|c|}{ Industry } \\
\hline & $\begin{array}{l}\text { Kuclear Power } \\
\text { Industry } \\
\end{array}$ & $\begin{array}{l}\text { Airline Pilots } \\
\text { and Crew }\end{array}$ & $\begin{array}{l}\text { Railroad } \\
\text { Operators }\end{array}$ & $\begin{array}{c}\text { Truck } \\
\text { Drivers }\end{array}$ \\
\hline $\begin{array}{l}\text { Consecutive } \\
\text { Hours Worked }\end{array}$ & 16 & 8 & 12 & 10 \\
\hline \multirow[t]{2}{*}{ Length of Break } & $\begin{array}{l}8 \\
\text { (after up to } \\
16 \text { hrs worked) }\end{array}$ & $\begin{array}{l}{ }^{8} \\
\text { (after } 8 \mathrm{hrs} \\
\text { aloft }\end{array}$ & $\begin{array}{l}10 \\
\text { (after } 12 \\
\text { cansecutive } \\
\text { hrs worked) }\end{array}$ & $\rightarrow$ \\
\hline & & & $\begin{array}{l}{ }^{8} \\
\text { (after } 12 \mathrm{n} \\
\text { of broken d }\end{array}$ & $\begin{array}{l}\text { rs } \\
\text { uty) }\end{array}$ \\
\hline $\begin{array}{l}\text { Hours Worked in } \\
\text { d 24-nrs Period }\end{array}$ & 16 & -- & -- & $\cdots$ \\
\hline $\begin{array}{l}\text { Hours worked in } \\
\text { d } 48-\mathrm{hr} \text { Pertod }\end{array}$ & 24 & - & -- & $\cdots$ \\
\hline $\begin{array}{l}\text { Hours Worked in } \\
\text { d } 7 \text {-day Period }\end{array}$ & 12 & 30 & -- & 50 \\
\hline $\begin{array}{l}\text { Hours Worked in } \\
\text { a } 30 \text {-day Period }\end{array}$ & -- & 100 & -- & $\cdots$ \\
\hline $\begin{array}{l}\text { Hours worked in } \\
\text { a Year }\end{array}$ & -- & 1000 & -- & -- \\
\hline
\end{tabular}

regulations are more detailed than the nuclear regulations and contain a variety of rules and exceptions for special situations (e.g., Alaskan bush pilots). For comparison in Table 5.1 , common measures of the number of working hours include number of hours worked per 24-hour period, 48-hour period, 7-day period, 30-day period and per year. All of the regulations summarized in the table permit increased work hours when emergencies or unusual situations occur.

As Table 5.1 shows, NRC policies and guidelines are the most lenient on two important measures:

1. Nuclear plant staff are permitted 15 consecutive hours of work, whereas pilots, railroad operators, and truck drivers are permitted only 8,12 , and 10 , respectively.

2. Nuclear plant staff are permitted 72 hours of work within a seven-day period, whereas pilots and truck drivers are permitted only 30 and 60, respectively. 


\subsection{CIJRRENT INDUSTRY PRACTICES}

Overtime for maintenance personnel is a common practice in the nuclear industry. One site we visited has about an $8 \%$ per year overtime rate, which includes the outage overtime. This translates to about 200 hours per year per man. During regular outage periods ten-hour shifts are scheduled per day for six to seven days a week for six to eight weeks. Other facilities examined estimated overtime for their maintenance personnel to be approximately 400 to 500 hours per year per person, or 16\%. In some cases, individuals had worked over 1000 hours per year of overtime, about 35\%. Several of the maintenance managers we interviewed indicated that 10 to $12 \%$ annual maintenance overtime constituted a "reasonable" amount of overtime.

Related industries were surveyed to compare their maintenance overtime practices with that of the nuclear power industry. As stated previously, the nuclear power industry experiences a 10 to $12 \%$ annual maintenance overtime which tends to incur during outages. The annual maintenance overtime for those industries surveyed, as shown in Table 5.2, ranges from 2 to $12 \%$.

There is little regulation for the industries surveyed that governs the amount of overtime maintenance personnel can work. The Federal Aviation Administration stated that while they to have regulations for the amount of overtime worked by pilots, they feel that overtime guidelines for maintenance mechanics is the domain of union contracts and company policy.

Our discussions on overtime with facility management revealed that in addition to overtime during outages, workers expect a routine amount of

TABLE 5.2. Annual Maintenance Overtime for Related Industries

\begin{tabular}{|lc|}
\hline Industry & Annual Matntenance Overtime \\
\hline Petrochemical & $2 \%$ \\
Afrlines & $2.1 \%$ \\
Fertilizer Manufacturer & $8 \%$ \\
Explosive Manufacturer & Less than $10 \%$ \\
Heavy Metal Processing & $10 \%$ \\
Chemical & $12 \%$
\end{tabular}


overtime in daily operations. Depending on current economic and social situations, this expected amount of overtime varies from facility to facility and among individuals. The younger personnel appeared to constitute the group most likely to pursue, expect, and work overtime. The financial benefits of overtime work (such as $11 / 2 \times$ base salary) were the most often cited reason for this situation. The pay also contributes to the desire to work overtine rather than shiftwork because the shift differential pay scale is significantly lower than the overtime pay scale. (A shift differential of $24 \$$ /hour was indicated at one facility consulted.)

\subsection{MAJOR PROBLEM AREAS WITH OVERT IME}

One of the major problem areas with overtime occurs during refueling outages, when the majority of overtine is worked. The second major problem area is the impact of preventative maintenance programs on the amount of overtime worked.

\section{3 .1 Outages}

The scheduling of overtime is especially critical during planned outages. Manpower, procedures, tooling, material, and scheduling requirements must he. coordinated for approximately 500 different jobs during a planned outage, depending upon the plant. The planning of manpower requirements during a scheduled outage can be broken down into five basic steps:

1. identify the tasks/jobs required to be performed, which provides the basis for workload

2. identify workload requirements (manhours/job or task), which will provide the basis for determining the number of maintenance personnel

3. identify availability of maintenance personnel to perform the outage jobs/tasks

4. using information on personnel availability, determine the needed amount of overtime

5. hased on the personnel available and the overtine required, determine the need for acquiring and number of additional offsite maintenance personnel. 
Because many variables must be factored into the manpower and overtime calculations, estimating overtime is difficult. Those variables include the following:

- union requirements for overtime scheduting

- productivity of personnel in protective clothing

- accumulated radiation exposure, which most likely differs for each individual in the work party

- time needed to train personnel for specific job assignments.

A major distinction among power plants is their approach to bringing in outside contractors during outages. Several of the larger utilities with multiple NPPs maintain central maintenance pools. These pools consist of personnel who specialize in outage activities and travel from plant to plant within the utility. This approach has proven to be extremely effective and beneficial by many of the maintenance managers we spoke to because it provides them with a force of qualified personnel who are knowledgable with their particular facility.

Continuous extended periods of overtime is a serious safety concern. During scheduled outages, personnel expect and can cope with a definitive period of overtime. However, when there is no specified end to overtime work, personnel often become disgruntled and fatigued by the overtime operations.

Interviews with maintenance personnel revealed the following reasons for the necessity of long hours:

- pressures to get the plant back on-line

- the many unanticipated maintenance activities that occur during an outage.

Regardless of the cause, large amounts of overtime are not conducive to yielding the degree of quality workmanship, concern for safety, and effective working relationships required at NPPs. Defining the level at which overtime becomes excessive would be a major undertaking. Several maintenance supervisors stated that, as per the current regulation, 16-hour days for 7 days 
straight is an excessive amount of overtime for maintenance personnel. Several factors influence the threshold at which overtime becomes excessive:

- the physical stamina and age of the individual

- the specific job activity (clean-up crew/person versus system trouble shooting)

- the impact to personal family relations.

As discussed, several managers indicated that a "reasonable" level of overtime ranged from 10 to $12 \%$ annually per person. Two major factors were given as influencing this estimate:

- Maintenance personnel desire financial benefits but grow dissatisfied with extended periods of overtime

- For unanticipated maintenance work and during outages, plant management is willing to authorize certain amounts of overtime rather than hiring additional permanent staff.

\subsubsection{Preventive Maintenance Programs}

Many people in industry feel that an effective and systematic preventive maintenance (PM) program can reduce the amount of overtime required. These programs can accomplish the following:

- prevent unexpected equipment failure

- minimize unscheduled outages

- reduce the duration and workload during scheduled outages. However, beyond the requirements imposed by the NRC for surveillance testing and inspection of safety-related systems, 1 ittle concrete effort is being directed at the area of preventive maintenance. Most of the plants visited have plans to place into effect systematic and rigorous preventive maintenance (PM) programs but, with one exception, implementation awaits additional manpower and a more concentrated push towards this objective.

The greatest impediment to an effective PM program was reported to be the lack of sufficient manpower to conduct scheduled PM tasks. At one nuclear plant, an estimated additional 15 people would be required to stay ahead of the corrective maintenance work sufficiently to accomplish PM tasks. This lack of 
maintenance personnel and the level of routine maintenance work have hindered several maintenance NPPs from developing a structured PM program (Seminara 1981). Yet, our industry contacts found one nuclear plant that had an effective PM program that decreased rather than added to the workload and corresponding manpower needs. Those plants presently in a "catch up" maintenance mode initially may need to add enough manpower to meet PM requirements.

\subsection{HIGHLIGHTS OF OVERTIME PROBLEM AREAS}

Based on our investigations thus far, the following items are the major safety-related issues concerning overtime work.

- A reasonable amount of overtime required for maintenance personnel in NPPs is very difficult to quantify. It varies from facility to facility and depends upon a variety of factors including staff size, training of personnel, the age of the equipment in the plant, union policies, corporate policies, worker expectations, and PM programs.

- Staffing requirements for new facilities are usually underestimated initially. This is due to the utility corporate philosophy that additional personnel should be justifiable and verifiable through concrete operating data. This situation unfortunately leads to the problem of always being "behind the eight-ball" as one maintenance supervisor described it; maintenance always being short-handed and behind in its tasks. 


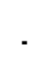

. 


\subsection{MAINTENANCE STAFFING LEVELS}

The maintenance staff in an NPP consists of a diversified group of individuals who can be broadly grouped into three areas: mechanics, electricians, and I\&C personnel. The maintenance staffing level refers the number of personnel available to maintain an NPP.

Many reports have been published and many more interviews conducted to determine how many maintenance personnel are employed in nuclear power electrical generating facilities (Hammon 1980; Johnson 1982; Personal Interviews). One major finding of these surveys and interviews is that maintenance departments vary greatly in size and composition. Although the justification for particular maintenance staffing levels is rarely documented, the actual staffing Tevels for operating NPPs have been well documented by the Edison Electric Institute (EEI) in its nuclear plant staffing survey of May 1980. Table 6.1 summarizes the EEI survey. Note the variation in the number of maintenance personnel for similar-sized facilities. For example, the maintenance staff for single-unit boiling water reactors (BWRs) ranges from 33 to 83.

This chapter will emphasize the issues that govern adequate staffing levels, including existing NRC guidance, staffing models, and factors influencing staff size. Information from those discussions will be used to identify the issues needing further study to determine what licensing actions the NRC should take concerning the way utilities determine their NPP maintenance staffing requirements.

\subsection{NRC GUIDANCE}

Whereas NRC guidance exists for the qualification and training of maintenance personnel, only a few NRC regulations concern staffing levels. The January 1, 1983, Code of Federal Regulations (10 CFR 50.34) concerning the FSAR for each facility requires the facilities to submit "Plans for conduct of normal operations, including maintenance, surveillance, and periodic testing of structures, systems, and components." A review of NUREG-0800, Standard Review Plan, and FSARs for both operating NPPS and plants soon to come on-line revealed that plants are not required to state their maintenance staffing level nor are they 
TABLE 6.1. Maintenance Staffing Levels (EEI Survey 1980)

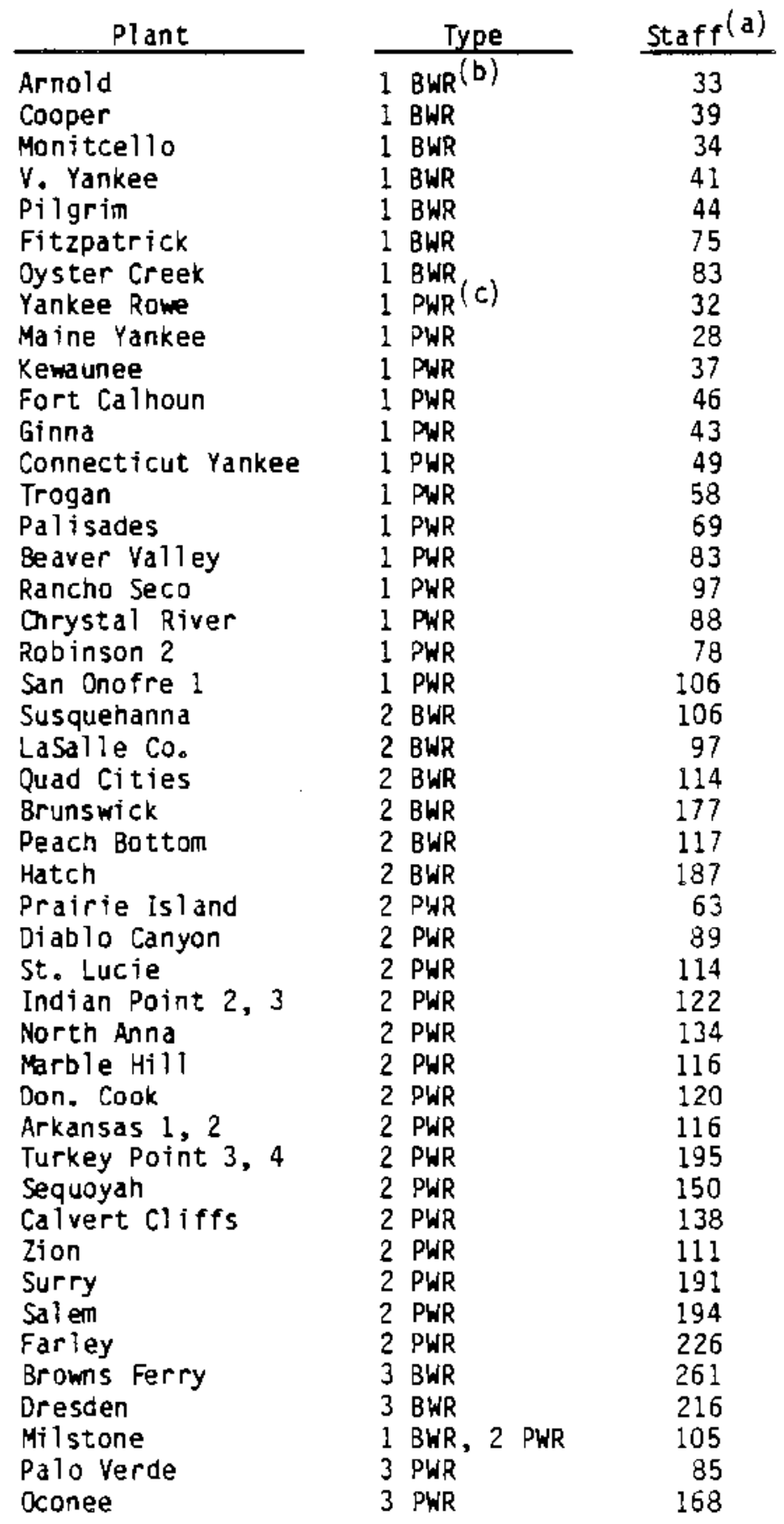

(a) All mechanical, electrical, and IsC personnel are included in the maintenance staffing level.

(b) $B W R=$ boiling water reactor.

(c) PWR = pressurized water reactor. 
required to submit any justifications for their maintenance staffing levels. Figure 6.1 is an excerpt from a typical FSAR. Note that the number of mechanics and electricians are stated "as required." The FSAR does not explain the criteria for "as required".

Our review of NRC regulations governing maintenance staffing levels can be summarized as follows:

- The NRC neither requires nor offers significant guidance for developing documented plans that incorporate key staffing factors in the decision process.

- The NRC has no mechanism that determines the adequacy of the maintenance staffing plans.

\subsection{STAFF ING METHODOLOGIES}

Interviews with various industry personnel revealed that one problem with maintenance staffing deals with aids in determining maintenance crew size. Although several utilities have started to develop a method for hiring personnel, the industry as a whole has received very little guidance on the number of personnel needed.

Although the nuclear industry does not generally use structured methodologies for maintenance staffing, they are commonly used in other areas. The military has developed several methodologies, including the Manpower Deterinination Model (MDM), the Interactive Manpower Aggregation Estimations System (IMAGES), and the Army Manpower and Personnel Requirements Process (ARMPREP). These methodologies develop manpower requirements from the required duties to determine staffing levels and could possibly be used in devaloping methodologies for the nuclear maintenance industry. Potential benefits include the following:

- assistance in selecting qualified staff

- help to convince maintenance of the need for additional manpower

- more efficient use of subcontractors

- possible reduction in overtime requirements 


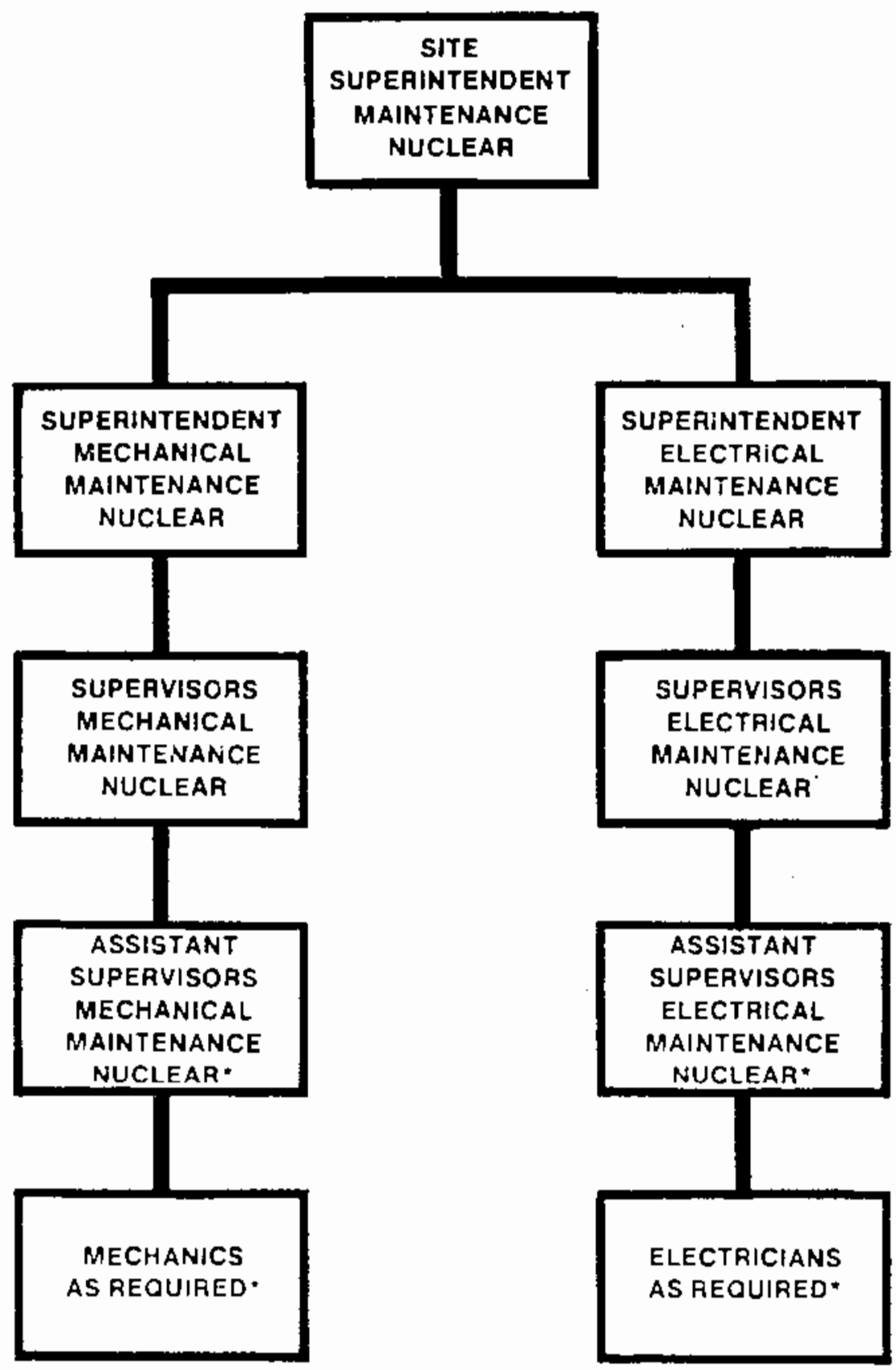

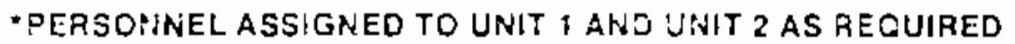

FIGURE 6.1. FSAR Excerpt on Staffing Levels 
- assistance in scheduling corrective and preventive maintenance programs.

\subsection{FACTORS INFLUENCING STAFF SIZE}

Interviews identified many factors as influencing the maintenance staff size:

- size of plant (1 unit, 2 unit, MW net)

- type of plant (PWR, BWR)

- age of plant

- personnel qualifications

- amount of overtime allowable

- preventive maintenance philosophy

- use of subcontractors

- maintenance budgets

- shiftwork policy/

- planning and scheduling of outages.

The qualifications, shiftwork, and overtime factors were discussed in previous chapters of this report. The remaining factors are examined in this chapter and can be separated into two categories: 1) factors reflecting the plant's physical aspects, and 2) factors influenced by plant management.

\subsubsection{Physical Factors Affecting Staffing Levels}

Physical factors that affect NPP maintenance staffing levels include the size, age, and type of plant.

\section{Plant Size}

Table 6.1 indicated that the number of reactor units at a facilty strongiy influences the size of the maintenance staff, as one would expect. The average maintenance staff for one-, two-, and three-unit NPPs is given in Figure 6.2 [based on the EEI Survey (1980)]. As the figure shows, the average maintenance staff is 58 for a 1-unit NPP, 137 for a 2-unit NPP, and 167 for a 3-unit NPP. Note the increase from 1 to 2 reactor units. The increase from 2 to 3 reactor units is somewhat less. 


\section{NUMBER OF REACTOR UNITS}

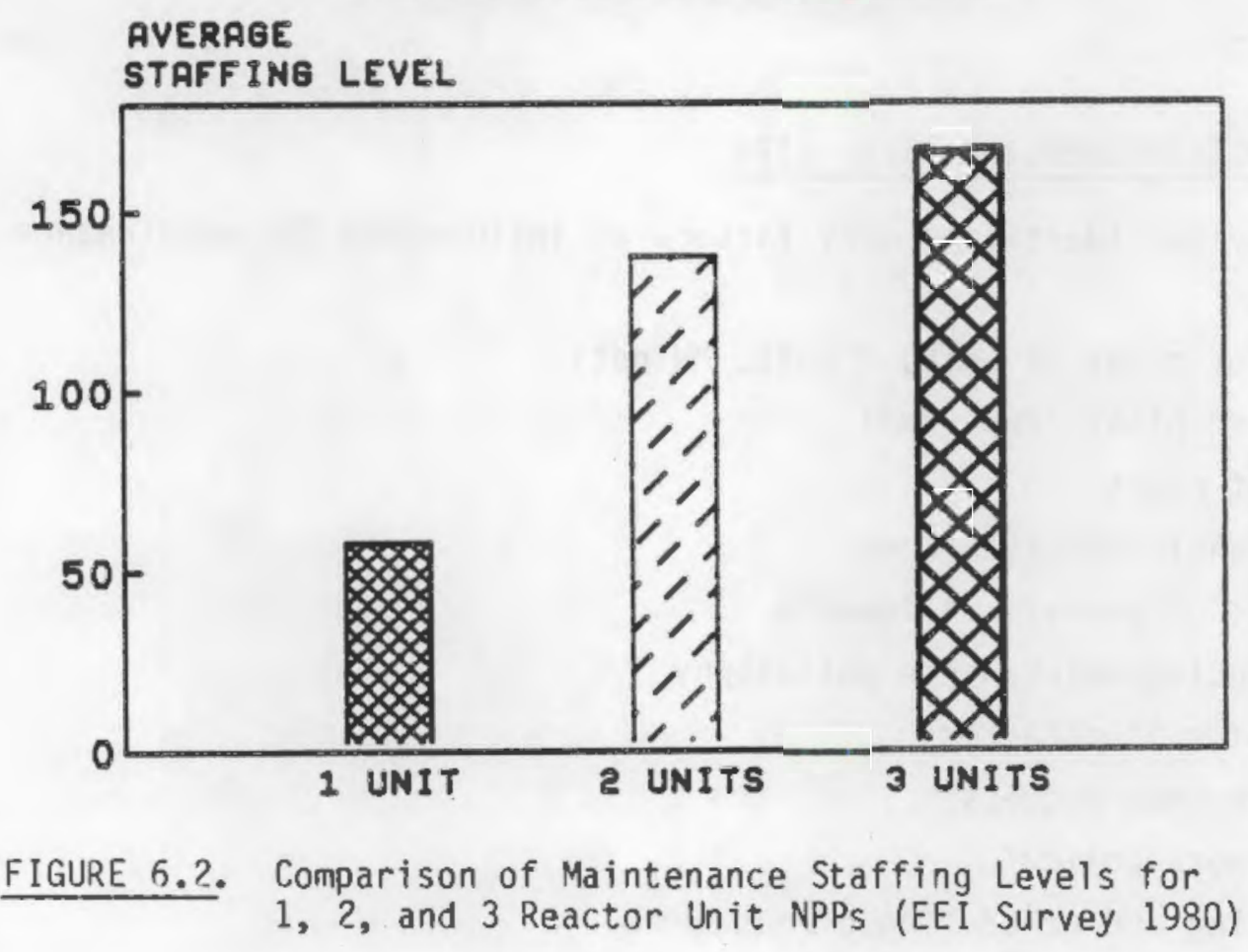

Plant Type

The information in Table 6.1 was matched with the type of reactor found in each facility to determine how the type of reactor affected an NPP's maintenance staffing level. The results of this analysis are shown in Figure 6.3 . The figure shows that there are no major differences between the maintenance staffing levels used on General Electric's boiling water reactors (BWRs) and Westinghouse's pressured water reactors (PWRs), although the staffing level for PWRs is consistently higher for both 1- and 2-unit NPPs. This indicates that although the type of plant does not appear to be a primary factor in determining maintenance staffing levels, it does have some influence on the size of the maintenance staff.

Plant Age

Our discussions with several maintenance managers indicated that they expected to increase their staff size to deal with increased maintenance tasks 


\section{SINGLE UNIT NPPS}

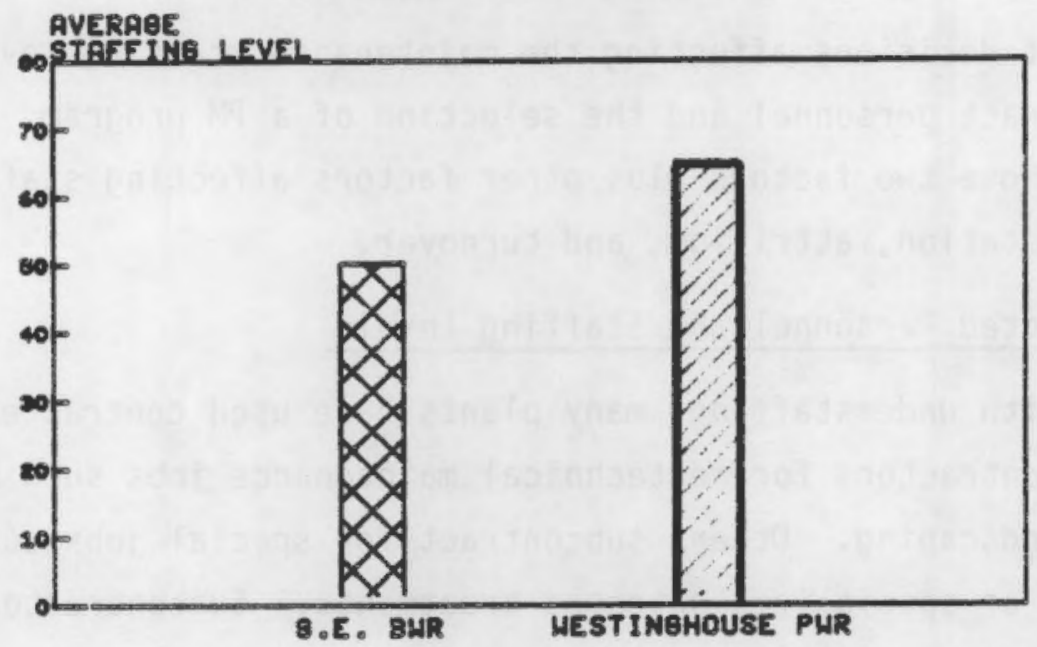

\section{DOUBLE UNIT NPPS}

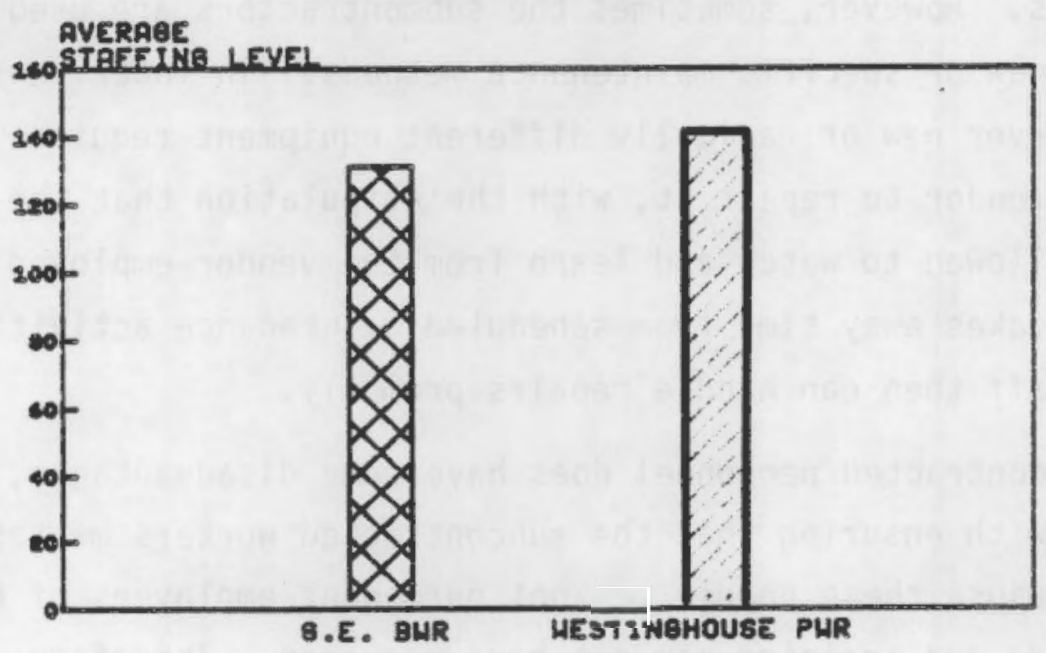

FIGURE 6.3. Comparison of Maintenance Staffing Levels for Plants Using Westinghouse PWRs and General Electric BWRs (EEI Survey 1980) 
as the plant ages. Evidence suggests that as a plant ages, health physic manpower requirements increase. There is little documentation of this subject, but we recommend this to be an area that should be examined in more detail.

\subsubsection{Management Decisions Affecting Staffing Levels}

Management decisions affecting the maintenance staffing level include the use of subcontract personnel and the selection of a PM program. This section will discuss those two factors plus other factors affecting staffing levels such as crew rotation, attrition, and turnover.

\section{Subcontracted Personnel and Staffing Levels}

To deal with understaffing, many plants have used contracted help. Some firms use subcontractors for nontechnical maintenance jobs such as painting, cleanup, or landscaping. Others subcontract for special jobs such as leaks, valve repairs, or specialized patented treatments. Subcontractors have served in many capacities on an industry-wide scale.

Subcontractors are often used to supplement manpower shortages in highneed situations. However, sometimes the subcontractors are used to teach utility personnel new or specific maintenance methods. In interviews, one company said that whenever new or radically different equipment requires maintenance, they hire the vendor to repair it, with the stipulation that the utility's mechanics be allowed to watch and learn from the vendor-employed mechanics. Although this takes away time from scheduled maintenance activities, experienced plant staff then can handle repairs promptly.

Using subcontracted personnel does have some disadvantages, however. One problem deals with ensuring that the subcontracted workers meet the utility's standards. Because these people are not permanent employees of the plant, standard methods and training may not have occurred. Therefore, the subcontracted organization might not employ personnel as qualified as those al ready used by the utility, which follows the guidelines given in ANS 3.1. This problem is similar to one in which new hires claim they can perform a task when 
they can't. This problem is more serious with subcontracted personnel, however, because the utility is limited in their ability to train them if they are not qualified. The assurance of efficiency, proficiency, and safety must come from the subcontractor.

Preventive Maintenance and Staffing Levels

One study has found that many plants apparently do not have enough maintenance staff to do both preventive and corrective maintenance (Badaiamente et al. 1982). This study suggested that sound PM prografls were not in place when the plants were started up. This lends to increasing manhour requirements for corrective maintenance. Many plants are therefore faced with having to increase their maintenance staff to effect a sound PM program.

Crew Rotation

For certain multiplant utilities, a corporate maintenance crew is available for refueling, for outages and for unexpected maintenance work. In this practice, personnel "float" from one plant to another, as needed.

One utility that uses this technique explained that the rotational crews consisted of highly skilled people, primarily welders, powerhouse mechanics, and IRC people. They are used in such jobs as turbine outages and major plant modifications. Because most of the rotational crew come from construction crews in this case, they are very familiar with the piants' design and improvements.

\section{Attrition and Turnover}

As was discussed in Chapter 2.0, turnover and attrition have been problems in the last few years. In the past, managers often dealt with their personnel for many years, but now many are reaching retirement age or are transfering to other positions, either within or outside the utility/nuclear industry. 


\subsection{STAFFING SECTION SUMMARY/RECOMMENDATIONS}

The problems identified in the review of staffing practices in the nuclear power industry highlight four major topics that merit further attention by the NRC:

1. Maintenance staffing level requirements depend upon key factors that vary dramatically across the industry and that include plant age, type, size, etc.

2. No consistent, validated strategy exists for estimating maintenance staff size requirements in the NPP industry.

3. The NRC neither requires nor offers significant guidance for developing documented plans that incorporate key staffing factors in determining staffing levels.

4. The NRC has no mechanisin to determine the adequacy of the maintenance staffing olans, as presented in the FSARs.

Because the type, age, size, and management of NPPs vary, no single standard for determining maintenance staffing requirements is feasible. Mowever, because of the impact of staffing levels upon problems such as overtine, the need for shiftwork, the use of contract personnel, etc., developing a general framework for setting maintenance staffing levels is important. Developing this framework for estimating staffing requirements would 1) enable the NRC to insure that the key problems are addressed consistently and verifiably, and 2) provide a basis for consistency in the NPP industry.

\subsubsection{Staffing Requirements Framework}

A framework for setting maintenance staffing levels would address all the major elements of the staffing problem (overtime policies, union constraints, shiftwork plans, power plant characteristics, etc.). Surveys of standard manpower optimization techniques and the techniques currently used in related industries could identify concepts that are applicable to the NPP industry. These tools could be combined into a framework to direct licensees on implementing the techniques so that overtime, shiftwork, preventative maintenance policies, etc., at their plant(s) would be addressed in a manner acceptable to 
the NRC. The result would be a consistent method of setting maintenance staffing levels that would allow adequate documentation of the rationale and assumptions used to determine the particular staffing levels. At the same time, the method also would have to address the variations in key staffing level factors such as plant size, age, type, etc. Possible inclusion of this approach into the NRC regulatory process is outlined below.

Possible NRC Regulatory Actions

A general framework for staffing NPP inaintenance could be integrated into existing NRC regulatory structure in the following areas:

1. expand the Standard Review Plan (SRP) (NUREG-0800) to include maintenance staffing

2. develop a NIJREG that describes the framework

3. establish an auditing tool for the NRC.

Expanding the SRP to include the framework for setting maintenance staffing levels would enable the NRC to insure that key factors in staffing were addressed when the Ticensee was preparing the PSAR/FSAR. A NUREG document could be developed to serve as a reference for the 1 icensees to use when developing the PSARS/FSARs. An important element of this document would be an outline of the documentation that the NRC will require when reviewing the PSARs/FSARs. The third potential item is developing acceptance criteria that would enable the NRC to perform field audits of licensee maintenance programs. 


\section{REFERENCES}

American Nuclear Society (ANS) 1971. Standard for Selection and Training for Nuclear Power Personnel. ANSI N18.1, Ta Grange Park, Illinois.

American Nuclear Society. 1978. Selection and Training of Nuclear Power Plant Personne1. Revision of N18.1-1971, ANST/ANS 3.1, La Grange Park, I1linois.

American Nuclear Society. December 6, 1979. Standard for Selection, Qualification and Training of Personnel for Nuclear Power Plants. ANST/ANS 3.1, La Grange Park, ITTinois.

American Nuclear Society. 1981. Selection, Qualification and Training of PerSonnel for Nuclear Power Plants. ANS 3.1, 1981, La Grange Park, Illinois.

Baldamente, R. V. et al. 1982. Recommended Program for the Development of Maintenance Guidelines for Nuclear Power Plants. PNL-4475, Pacific Northwest Laboratory, Richland, Washington.

Baldamente, R. V. et a1. 1983. Development of Guidelines for Upgrading Maintenance Procedures in Nuclear Power Plants: Interim Report. Pacific Northwest Laboratory, Richland, Nashington.

Beaver Valley-2 Nuclear Power Station. Final Safety Analysis Report. Duquesne Light Co., Shippingport, Pennsylvania.

Byron/Braidwood Nuclear Power Stations. Final Safety Analysis Report. Commonwealth Edison $\mathrm{C}_{0} .$, Illinois.

Department of the Air Force. April 1, 1974. Instructional System Developinent. AFM 50-2, Washington, D.C.

Department of Labor. 1977. Apprenticeship Programs. Federal Register, Vol. 42, No. 34 - Friday, February 18, 1977. U.S. Government Printing office, Washington, D.C.

DeYoung, R. C. 1983. Testimony of Richard C. DeYoung, Director of the Dffice of Inspection and Enforcement U.S. Nuclear Regulation Commission, on Quality Assurance for Nuclear Power Plants. Testimony before the Committee on Labor and Human Resources, United States Hearing on Labor Corruption. June 29, 1983. J.S. Envernment Printing office, Washington, D.C.

Edison Electric Institute. May 1980. Nuclear Plant Staffing Survey. Edison Electric Institute, New York, New York.

Evans, R. January 1983. "Measuring the Cost Effectiveness of Training." Power Engineering. $\mathrm{pp}$. 50-52.

Folkard, S. and T. H. Monk. 1979. "Shiftwork and Performance." Human Factors. $21: 483-492$. 
Hatch, 0. 1983. "Statement of Senator Orin Hatch - Hearings Overseeing the Boilermakers Union." In News from the Labor and Human Resources Committee. Washington, D.C.

Hope Creek-1 Nuclear Power Station. Final Safety Analysis Report. Public Service Electric and Gas Co., SaTem, New Jersey.

Johnson, R. C. 1982. Manpower Requirements in the Nuclear Power Industry. ORAU-205, Oak Ridge Associated Universities, Oak Ridge, Tennessee.

Institute for Nuclear Power Operations. 1981. Guidelines for Mechanical Maintenance Personnel Qualification. GPG-05, INP0, Atlanta, Georgia.

Institute for Nuclear Power Operations. 1982. Performance Objectives and Criteria for Plant Evaluations. Institute for Nuclear Power Operations, At1anta, Georgía.

Marble Hill-l Nuclear Power Station. Final Safety Analysis Report. Public

Service Indiana, Jefferson Co., Indiana.

Midland-l and 2 Nuclear Power Stations. Final Safety Analys is Report. Consumers Power Co., Midland, Michigan.

Millstone-3 Nuclear Power Station. Final Safety Analysis Report. Northeast Utilities, Waterford, Connecticut.

Nine Mile Point-2 Nuclear Power Station. Final Safety Analysis Report. Niagara Mohawk Power Corporation, Scriba, New York.

Rittenhouse, R. C. September 1982. "Training, Education and Staffing for Power Plants." Power Engineering. pp. 42-50.

Seminara, J. L. and B. 0. Parsons. 1981. Human Factors Review of Power Plant Maintainability. Electric Power Research Institute (EPRI), NP-1567, Palo Alto, California.

U.S. Code. Title 10, Sec. 50.34.

U.S. Code. Title 20, Sec. 29.

U.S. Code. Title 47, Sec. 23836.

1J.S. Nuclear Regulatory Commission. September 1975. Reissued May 1977. Personnel Selection and Training. Regulatory Guide 1.8, U.S. Nuclear Regulatory Cominission, Washington, D.C.

U.S. Nuclear Regulatory Commission. February 1979. Proposed Revision 2 to Regulatory Guide 1.8, Personnel Selection and Training. U.S. Nuclear Regulatory Commission, Washington, D.C.

U.S. Nuclear Regulatory Commission. May 1980. Action Planned Developed at a Result of the TMI 2 Accident. NUREG-0660, U.S. Nuclear Regulatory Commission, Washington, D.C. 
U.S. Nuclear Regulatory Commission. September 1980. Personnel Section and Training. Regulatory Guide 1.8, U.S. Nuclear Regulatory Commission, Washington, 0.c.

1).S. Nuclear Regulatory Commission. November 1980. Criteria for Preparation and Evaluation of Radiological Emergency Response PTan and Preparedness in Support of Nuclear Power Plants. NUREG-0654, U.S. Nuclear ReguTatory Comis sion, Washington, D.C.

U.S. Nuclear Regulatory Comnission. July 1981. Training. Section 13.2 of NUREG-0800, IJ.S. Nuclear Regulatory Commission, Washington, D.C.

U.S. Nuclear Regulatory Comnission. Fall 1981. Standard Technical Specifications for Westinghouse Pressurized Water Reactors. NUREG-045?, U.S. Nuclear Regulatory Comission, Washington, D.C.

Watts Bar-1 Nuclear Power Station. Final Safety Analysis Report. Tennessee Valley Authority, Spring City, Tennessee.

Wegner, W. M. 1980. Power Plant Staffing. NUREG/CR-1280, U.S. Nuclear Regulatory Commission, Washington, D.C. 
PNL -5119

UC-97d

$\underline{\text { DISTRIBUTIDN }}$

OFFSITE OFFSITE

20 Dr. J. P. Jankovich

Licensee Qualifications Branch

Division of Human Factors Safety

Office of Nuclear Reactor Regulation

Mail Stop 228

U.S. Nuclear Regulatory Cormission

Washington, D.C. 20555

2 NRC Division of Technical Information and Document Control

27 DOE Technical Information Center

ONSITE

DOE Richland Operations Office

H.E. Ransom

50 Pacific Northwest Laboratory

W. B. Ashton

R.V. Badalamente (15)

A.J. Boegel (5)

J.L. Bryant

A.D. Chockie (10)

C.J. Hostick (5)

C.H. Imhoff

M. Morganstern (HARC)

J. 01 sen (HARC)

W. Rankin (HARC)

R.J. Sorenson

S.C. Vickroy

R.D. Widrig

Publishing Coordination (1)

Technical Information (5) 


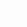

